\title{
THE SELECTION OF FEDERAL HEARING EXAMINERS: PRESSURE GROUPS AND THE ADMINISTRATIVE PROCESS
}

\author{
MORGAN THOMAS†
}

A LITTLE-NoxiCED circular from the Civil Service Commission last December $13^{1}$ heralded the end of one of the bitterest behind-thescenes fights Washington has seen in recent years. The controversy dated back to June 11, 1946, when the American Bar Association's efforts to make the Federal Government's regulatory processes more "judicial" were realized in enactment of the Administrative Procedure Act. ${ }^{2}$ It came to a head on March 11, 1949, when the Civil Service Commission accepted the recommendations of a group which was dominated by prominent American Bar Association members and ordered the firing of over $25 \%$ of the hearing examiners then employed by federal agencies. The December 13 circular in effect rescinded that order and set aside almost everything the private group had done.

To understand the controversy it is necessary to review the role of the hearing examiner under the Administrative Procedure Act. In general the Act revised and made uniform throughout all federal agencies the procedures for administrative hearings and decisions in both adjudication and rule-making. Integral to the new procedures was the creation within each agency of a special corps of hearing examiners independent of agency control of influence: only they could preside at formal hearings and render initial decisions except in those infrequent instances when agency members themselves performed those functions.

Since each agency previously had a staff of trial examiners which did these things, the main change lay in the new independence which hearing examiners were to have. To that end they were explicitly made free of supervision by the investigatory, prosecuting, and administrative staffs of their agencies; and in certain adjudications they were even forbidden to consult ex parte with interested parties or

$\dagger$ Assistant Professor of Political Science, University of Mfichigan.

1. Civil Service Commission Departmental Circular No. 592, Supp. 3 (DC 592, S.3) (December 13, 1949).

2. 60 StaT. 237, 5 U.S.C. $\$ 1001$ (1946). A short summary of previous attempts to pass a bill on administrative procedure will be found in Administralize Procedure Act, Legislative History, Sex. Doc. No. 248, 79th Cong., 2d Sess. 63-6 (1946). That the Administrative Procedure Act was in effect sponsored by the American Bar Association is verified by this statement concerning S. 7, the bill which, with some fev changes based on agency and other objections, became law as the Administrative Procedure Act: "S. 7 and H.R. 1203, introduced in the first session of the Seventy-ninth Congress, are similar to S. 2030 and H.R 5081, and represent the latest recommendations of the Ameriean Bar Association for legislation to improve the administration of justice" Statement by Mr. C. A. Miller, Chairman, American Bar Association Committee on Administrative Law for the District of Columbia, Sen. Doc No. 248, 79th Cong, 2d Sess. 66 (1946). 
with investigating or prosecuting officials. ${ }^{3}$ Within each agency cases were generally to be rotated so that agency influence could not be made effective through assignment of cases. ${ }^{4}$ Moreover, the Civil Service Commission was entrusted with the broad powers which the agencies themselves had previously exercised over their trial examiners. Thus the Commission was given authority to prescribe examiners' grades and salaries and to pass on promotions independently of agency ratings or recommendations. ${ }^{5}$ And an examiner could be removed only if "good cause" were established at a Civil Service Commission hearing. ${ }^{6}$

These provisions seem clear enough. But the wording of another provision, that covering the initial selection of hearing examiners, gave rise to two major ambiguities which have not yet been clarified over three and a half years after passage of the Act. The provision, which appears in Section 11 of the Administrative Procedure Act, was this:

"Subject to the civil-service . . . laws ... there shall be ap" pointed by and for each agency ... qualified and competent examiners. ..."

The first question posed by this language was what part, if any, the Civil Service Commission was to play in the selection of examiners. Both the House and Senate Committees on the Judiciary explained the words in identical terms:

"That examiners be 'qualified and competent' requires the Civil Service Commission to fix appropriate qualifications and the agencies to seek fit persons ... [S]elf interest and due concern for the proper performance of public functions will inevitably move agencies to seek the highest type of examiners." t

Thus it appears that Congress intended the Commission merely to draw up a set of general standards to be applied by the agencies in determining whether particular applicants should be appointed. Yet a diverse view was soon urged: that the Commission should go further

3. Administrative Procedure Act, Section 5(c); 5 U.S.C. $\$ 1004$ (c) (1946).

4. Administrative Procedure Act, Section 11; 5 U.S.C. $\$ 1010$ (1946).

5. Ibid.

6. Ibid. The reasons for these provisions of Section 11 have been explained as follows: "The purpose of this section is to render examiners independent and secure in their tenure and compensation. The section thus takes a different ground than the present situation, in which examiners are mere employees of an agency, and other proposals for a completely separate 'examiners' pool' from which agencies might draw for hearing officers. Recognizing that the entire tradition of the Civil Service Commission is dirceted toward security of tenure, it seems wise to put that tradition to use in the present case." Report of the Senate Committee on the Judiciary on S. 7, SEN. Rep. No. 752, 79th Cong., 1st Sess. (1945), reprinted in Sen. Doc. No. 248, 79th Cong., 2d Sess. 215 (1946).

7. SEN. DoG. No. 248, 79th Cong., 2d Sess. 215, 280 (1946). 
and determine whether each individual applicant was qualified, the agencies being limited to making their selections from names submitted by the Commission.

The second question was whether those who held trial examiner jobs when the Act became effective and had given satisfactory performance would have to requalify. A subordinate question was whether those incumbents holding "war-service" or "temporary" appointments should be treated the same as those with competitive civil-service status. ${ }^{8}$ In other words, what differentiation was to be made between three clearly defined groups-status incumbents, nonstatus incumbents, and new applicants? On this score the congressional history was silent. One view was that if Congress had intended any screening of incumbents it would have said so. The job content remained the same since, by the terms of the Act, trial examiner positions were automatically converted into hearing examiner positions. By their actual performance the incumbents had demonstrated their qualifications. And the legislative history contained no criticism of the existing corps of trial examiners. The contrary view was that Congress had, without saying so, in effect abolished all the old trial examiner jobs, ordered those who held them to be fired, and created a whole new set of jobs for which all comers must compete on equal terms. An intermediate view was that the Commission could and should require incumbents to requalify but should give some sort of preference to those with competitive status.

Thus, while passage of the Administrative Procedure Act ended, at least temporarily, the battle over regulatory procedure, an enticing opportunity for affecting the administrative process now lay in the selection of those who would apply it in the primary instance-the hearing examiners. The opportunity was not disregarded.

\section{The Story of the Qualifying Process}

The Civil Service Commission proceeded very slowly. Under the Act the selection of the hearing examiners was not to become effective until one year after the Act was approved, namely June 11, 1947. The Commission's first official act was to appoint an advisory committee to aid in drafting rules for the selection, classification, promotion, and

8. These were all men who had received status under the provisions of the Ramspeck Act of November 26, 1940, "Extending the Classified Executive Civil Service of the United States," 54 STAT. 1211, 5 U.S.C. $\$ \$ 631$ (a), 631(b), 632, 635, 669, 681-4 (1946), and Exec. Order No. 8743, April 23, 1941, 5 Code Fed. Recs. 927 (Cum. Supp. 1943) issued purstant thereto, by which incumbents of attorney positions were granted civil service status. These incumbents had thus served prior to March 16, 1942, after which date, under War Service Regulations issued by the Commission pursuant to Exec. Order No. 9063, Feb. 16, 1942, 1 Code Fed. Regs. 1091 (Cum. Supp. 1943), only "war-service" appointments were made. 
removal of hearing examiners. The advisory committee consisted of agency personnel with the exception of Carl McFarland, first Chairman of the Section of Administrative Law of the American Bar Association. ${ }^{9}$ Mr. McFarland was the representative of the leadership of the American Bar Association. He had been instrumental in securing the passage of the Administrative Procedure Act, and he had urged in 1945 that the Association follow closely and attempt to control the implementation of any administrative procedure act which might be passed.10 In line with this plan, the American Bar Association Journal commended the selection of Mr. McFarland for the advisory committee and counselled that "a high responsibility of the organized Bar will be to follow closely all developments as to the selection of . . . examiners. . . ."11 The Association's attitude towards the incumbents could be easily gleaned from several articles printed in the American Bar Association Journal. ${ }^{12}$ Typical was an article which included with warm approval the following quotation of a letter to Civil Service Commissioner Arthur S. Flemming from Senator Wiley, who became Chairman of the Senate Judiciary Committee when the Eightieth Congress convened in 1947 :

"It seems to me that the burden of proof is on the United States Civil Service Commission that these hearings [sic] examiners will not be men of leftist thinking, men who don't have complete loyalty to our constitutional system of checks and balances, men who are not devoted to our system of private enterprise. ... I shall be looking for substantial proof that the Civil Service Commission is going to fill these quasi-judicial posts with men of the highest unimpeachable caliber of the legal profession available, rather than with men who simply have occupied similar positions in the Federal Government today, who largely are of one party and who may lack the approach of private enterprise in their work." ${ }^{13}$

On May 29, 1947, on the assumption that Section 11 of the Administrative Procedure Act would become effective on June 11, 1947, the

9. The other members were: J. Haden Alldredge, Interstate Commerce Commissioner; W. Carroll Hunter, Solicitor of the Department of Agriculture; F. C. Baggarly, Chief Trial Examiner of the Federal Trade Commission; and Herbert A. Bergson, Chicf Legal Consultant in the Office of the Assistant Solicitor General, Department of Justice.

10. Mr. McFarland's Special Committee on Administrative Law reported that "the legislation which may be secured could be wasted in large part by the failure of the Association to make provision for adequate follow-up. . . . Special attention should also be given to the examiner system, both in personnel and operation. ..." "Business and industry generally, when proposals for administrative powers and legislation arise, by nature confine themselves to questions as to whether or not the powers should be conferred or the subject regulated at all." These quotations are from the Supplemental Report of the Special Committee on Administrative Law, 70 A.B.A. REP. 272, 273-4 (1945).

11. 33 A.B.A.J. 1 (1947).

12. See id. at 213 ; id. at 421 .

13. Id. at 422 . 
Civil Service Commission issued its first regulation pertaining to hearing examiners. This regulation allowed the agencies to make conditional reappointments of incumbents of positions that were hearing examiner positions under the Administrative Procedure Act. ${ }^{14}$ Pursuant to this regulation, the agencies "conditionally reappointed" their one hundred and ninety-seven incumbent hearing examiners. ${ }^{15}$ Shortly thereafter the Civil Service Commission announced to the agencies that no personnel action could be taken in regard to hearing examiners without permission of the Civil Service Commission. ${ }^{16}$

Alarmed by these decisions Senator Wiley wrote another letter to Commissioner Arthur S. Flemming dated June 20, 1947, also reprinted in the American Bar Association Journal:

"[C]ertain very disturbing allegations have been communicated to me to the effect that the Commission may pursue a course during the period when Congress may not be in session which it would not otherwise pursue were the Congress still at hand in Washington. ... As you know, I have shared the intense concern of the American Bar Association that the Hearing Examiners ultimately confirmed for the new posts might consist largely or exclusively of an entrenched 'palace guard' of former Examiners and/or of individuals having an approach inimical to the welfare of private enterprise." 17

On June 28, 1947, the Commission published Proposed Regulations for the appointment, compensation, and removal of hearing examiners and gave notice of a public hearing on them..$^{18}$ The public hearing was

14. The regulation, issued as Part 34 of its Rules and Regulations, read as follows:

"Part 34-Appointment, compensation and removal of hearing examiners.

"Section 34.1 as set out below is hereby added to the regulations in Part 34.

"Section 34.1 Conditional re-appoiniment of hearing examiners. Pending promulgation of final regulations by the Commission, incumbents of positions that are hearing examiner positions on June 11, 1947, may be re-appointed conditionally on that date. Any eligibility for permanent appointments of incumbents that may be granted in the final regulations shall be based on the status of incumbents on June 11, 1947 (Section 11, 60 Stat. 244; 5 U.S.C. Supp. 1010)." 12 FED. REg. 3507 (1947).

Also, Civil Service Commission Departmental Circular No. 592 (DC 592) (June 3, 1947) was sent to heads of departments and independent establishments to inform them of this personnel action, i.e., the conditional re-appointment of hearing examiners.

15. 64 Civil Service Comarrssion ANn. Rep. 30 (1947). The Civil Service Commission's resort to this formula of "conditional reappointment" was an attempt to foreclose the argument that any incumbent allowed to continue in his job after June 11, 1947 automatically became entitled to the protection of the removal provision of Section 11 (5 U.S.C. \$1010) whether or not an official absolute appointment had been given to the incumbents.

16. Civil Service Commission Departmental Circular No. 592, Supp. 1 (DC 592, S.1) (June 18, 1947).

17. 33 A.B.A.J. 689 (1947).

18. 12 FED. REG. 4233 (1947). 
held on July 9, 1947; and on September 23, 1947, the Commission promulgated its Final Regulations. ${ }^{19}$

The Proposed Regulations mentioned that qualifications examinations would be conducted by a Board of Examiners "as a section within the Examining and Placement Division" of the Commission to consist of three members, of which only one was to be an employee of the Commission. ${ }^{20}$ This provision was omitted in the Final Regulations, but in an accompanying statement the Commission made known that for rating incumbents with civil service status a Board of Examiners with at least two experts in administrative law from outside the government would develop standards and rate status incumbents on the manner in which they had discharged their duties. ${ }^{21}$ This was the first public announcement that the rating board would include members from outside the government, that it would have considerable discretionary authority to formulate rating standards, and that the board would function like a committee of expert examiners apart from the Civil Service Commission's regular personnel examining staff.

The American Bar Association Journal was prompt in noting its approval of this set-up and it reported that Mr. McFarland, as its member on the advisory committee, had accomplished a "signal victory" in regard to the Final Regulations. In an article entitled "Victory As To The Hearing Examiners: Association's Contentions Sustained As To New Rules," the Journal reported it in these words:

"Of the nine principal points made in behalf of our Association by way of objection to the draft of rules on which the Commission's hearing of July 9 was held, the Commission sustained eight in full and adopted as to the ninth a compromise which will need to be watched carefully as to the manner in which it is carried out but cannot be said to contravene the mandates or the intent of the Act. Qualified 'outsiders' will not be placed on a parity with incumbent Examiners as to rating for appointment, but the present Examiners will be subjected to rigorous investigation, with an examination by an independent board of 'outsiders.'

"This signal victory on eight items and substantial victory on

19. 12 Fed. Reg. 6321 (1947) ; Federal Personner Manual, c. 21, Part 34. Thise Final Regulations may also be found in 5 CODE FED. REg. 409-14 (Supp. 1947) and 5 Code Fed. REg. 185-90 (1949 ed).

20. §34.3, 12 FED. REG. 4233 (1947).

21. The accompanying statement of September 23, 1947, announced this on page 2 as follows: "The Commission will establish a Board of Examiners to be made up of one person now on the Commission's staff and at least two persons from outside the government who have an outstanding reputation in the field of administrative law.... In accordance with standards to be developed by the Board, the Commission will make a complete qualifications investigation of the incumbents [with competitive status] to determine the manner in which they have discharged their duties and responsibilities in the positions now held by them as well as in previous positions." (Emphasis added). 
the ninth was not won without a great deal of work against strong opposition which at times seemed likely to have its way in the new rules. Carl McFarland, of our Association, as the non-governmental member of the Commission's Advisory Committee 'stuck to his guns' for many months in urging our Association's contentions. Chairman Wiley of the Senate Committee on the Judiciary made his interest and concern very clear to the Commission and the agencies." 22

In brief, the Final Regulations made civil service rules and regulations applicable to hearing examiners and provided additional restrictions on any agency action concerning hearing examiners. ${ }^{23}$ Incumbents with civil service status had to pass a non-competitive examination with a score of 70 in order to be eligible for an absolute appointment as a hearing examiner. ${ }^{24}$ However, the Civil Service Commission announced that "only those [status] incumbents who in the judgment of the Board [of Examiners] are eminently qualified to carry on the duties of hearing examiners will receive absolute appointments to such positions." 25

Incumbents without civil service status, like new applicants, would have to pass an open competitive examination and obtain a score within reach of certification from a competitive ranked register of eligibles for each pay grade.

The Announcement for Examination for Hearing Examiner was issued on October $21,1947 .{ }^{26}$ It divided the experience requirement into general and specialized with correspondingly fewer years of general experience and more years of specialized experience required for

22. 33 A.B.A.J. 861 (1947).

23. Thus, all appointments had to have the prior approval of the Commission with regard to qualifications and status $(\$ 34.4)$; promotions, reassignments, transfers and reinstatements had to be generally on a competitive basis ( $\$ \S 34.5,34.6)$; within-grade salary advancements would be made without the use of agency efficiency ratings ( $\$ \$ 34.7$, 34.8 ); and removals could be made only after the Commission had determined that good cause existed upon the basis of the record of a hearing (\$34.11). See note 19 rspro.

24. For a detailed explanation of the regulations, see Civil Service Departmental Circular No. 592, Supp. 2 (November 5, 1947) (hereafter cited as DC 592, S.2).

25. Emphasis added. DC 592, S.2, p. 2, and statement accompanying Final Regulations, p. 2. These releases also explained briefly the procedure for the qualifications determination for status incumbents. The incumbent would file a statement of his previous training and experience; a qualifications investigation would be made by means of personal interviews with persons qualified to give information relative to the incumbents; incumbents would be required to appear before the Board of Examiners for an oral interview; and the Board of Examiners would make the ratings.

26. Civil Service Commission Examining Circular No. 17 (Oct. 21, 1947) (hereafter cited as EC-17). 
each higher grade of position. ${ }^{27}$ General experience was mainly legal work in some field in which government regulation is conducted through the device of hearings. Specialized experience involved legal work as a judge, or in a governmental regulatory body, or in practice before a governmental regulatory body or court of record. Along with the Proposed Rules had been issued a tentative Examination Announcement which set forth requirements of qualifying experience for the position of hearing examiner. The American Bar Association Journal objected strenuously to one type of specialized qualifying experience.

"[This] proposes to count as required experience 'administrative charge or responsibility for the successful completion of cases conducted before a court of record or governmental regulatory body.' So far as this opens the door to appointments from among people whose experience has been the 'administrative charge . . . of cases conducted before a . . . governmental regulatory body' it would include persons who are expediters, coordinators, paperpushers and the like who are hardly more than chief clerks or political supervisors and are without real professional experience or qualification." 28

Under the section of the Announcement entitled "Basis of Ratings," ten different rating factors were set forth without indication of what weight each would carry. Eight of them dealt generally with legal or judicial ability. One dealt with "diversity of experience in legal proceedings of the type described above." The other dealt with "knowledge and experience in the technical subject-matter field involved in the position." A specific overall requirement was that "applicants must also show conclusively that they are persons of judicial temperament and poise." ${ }^{29} \mathrm{By}$ number alone, then, these rating factors stressed the importance of general legal and judicial qualities in preference to specialized economic and legal knowledge of a subject-matter field of regulation.

The membership of the Board of Examiners for Hearing Examiner

27. The following experience table was included in the Announcement:

EXPERTENCE REQUTREMENT TABLE

$\begin{array}{cccc}\begin{array}{c}\text { Grade of } \\ \text { Position }\end{array} & \text { Total } & \begin{array}{c}\text { Amount of Experience } \\ \text { General }\end{array} & \text { Special } \\ \text { P-8 } & 6 & - & 6 \\ \text { P-7 } & 6 & - & 6 \\ \text { P-6 } & 6 & 1 & 5 \\ \text { P-5 } & 6 & 2 & 4 \\ \text { P-4 } & 6 & 3 & 3\end{array}$

This entailed ratings for each of the five grades of positions and therefore five separate registers applying to all agencies of the government using hearing examiners.

28. 33 A.B.A.J. 863 (1947).

29. EC-17 at 1 . 
Personnel which was to function pursuant to the terms of the Announcement and the Civil Service Commission's regulations was finally announced on January $23,1948 .{ }^{30}$ The Board consisted of six persons. Two were state supreme court judges; one was an employee of the Civil Service Commission; and three were practicing attorneys who had held high posts in the American Bar Association. ${ }^{31}$

As the Board of Examiners was beginning to process the applications from incumbents with civil service status, in May, 1948, its function of making qualifications determinations was extended to include non-status incumbents and non-incumbent applicants. ${ }^{32}$ This additional function included the rating of qualified eligibles for a ranked register, because these applicants were subjected to a competitive examination. The original six members of the Board of Examiners took on the task of qualifying and rating the non-status incumbents; but for non-

30. See 34 A.B.A.J. 179 (1948). The group so appointed have always referred to themselves as "consultants," although the Civil Service Commission has referred to them as the Board of Examiners for Hearing Examiner Personnel. They will be called the Board of Examiners in this article.

31. The two judges were Douglas L. Edmonds of California and Laurance $\mathrm{MI}$. Hyde of Missouri. The Commission employee was Wilson Mr. Matthews. The three attorneys were Carl McFarland, Chairman of the American Bar Association's Committee on Administrative Law, 1941-46, and a member of the Minority Group on the Attorney General's Committee on Administrative Procedure; Joseph W. Henderson, former President of the American Bar Association, 1943-44; and Willis Smith, former President of the American Bar Association, 1945-46. The Antrican Bar Association Joumal noted that Judge Edmonds comes from "a state which separates examiners completely from the agencies," 34 A.B.A.J. 179 (1948). But neither of the judges had applied foderal administrative law. Mr. Smith is the senior partner in the law firm of Smith, Leach \& Anderson in Raleigh, North Carolina, whose clients include Armour and Company, and International Paper Company, which have been extensively involved in litigation before administrative agencies. Mrr. Henderson is a member of the firm of Rawle \& Henderson in Philadelphia, Pennsylvania. His firm has represented the following concerns in cases before the NLRB: Republic Steel Corporation, Southern Steamship Corporation, and Berkshire Knitting Mills. While acting as a member of the Board of Examiners, AIr. Henderson was counsel for American MTanufacturing Company in a proceeding in a regional office of the NLRB. Mr. MicFarland, the Chairman of the Board of Examiners, is connected with the law firm of MIcFarland \& Sellers in Washington, D.C. He recently" has been chief counsel for the National Association of Mfanufacturers in the case to challenge the constitutionality of the Regulation of Lobbying Act: NAMI v. Clark pending before the District Court of the District of Columbia. (Case \#381-48). The firm represents a number of Stock Yards Companies before the Department of Agriculture. Mr. Ashley Sellers, Mr. MIcFarland's partner, was for many years in the Solicitor's Office of the Department of Agriculture and was later Assistant War Food Administrator. Its clients are mostly from business firms, although MIr. AIcFarland has acted for some Railway Brotherhoods in injunction proceedings.

32. First Report of the Consultants to the U.S. Cruil Service Covonssion, Hearing Examiner Personnel under the Administrative Procedure Act 6, (Jan. 31, 1949). (Hereafter cited as FIRST REPORT of the Consultarts.) This report is reprinted in 95 Cong. Rec. A1567-A1571 (Miarch 16, 1949). 
incumbent applicants, the Civil Service Commission, "on the recommendations of the original group of consultants," ${ }^{33}$ appointed nine associates, each to act in the several regions of the country as a single personnel examiner for the non-incumbent applicants in his region. ${ }^{34}$ Each member of this group of associates functioned as a preliminary grader of applicants in his area, on the basis of the applicant's statement of his qualifications and of an oral interview. Thereupon, these associates informed the Board of Examiners as to "their judgment and findings in each case either by mail or orally at the November-December 1948 meeting. All such cases were either discussed with, or carefully reconsidered on the paper record by, regular consultant member's of the group." 35

For incumbents, the Board of Examiners recommended, and the Civil Service Commission approved, that open competitive standards would be used in examining all hearing examiners whether or not they had civil service status. ${ }^{36}$ Thus, all incumbents were to be treated essentially alike in the qualifying process; and in the spring of 1948, regular Civil Service Commission personnel investigators were used to build up a record of opinions about the incumbents. These qualifications investigators were lawyers. How widely they consulted the references (listed by the incumbents) and other persons who at that time or in the past had supervised the incumbents is not known. ${ }^{37}$

33. First Report of the Consultants 7.

34. These associates are listed in the FrRst REPORT OF THE Consultants as follows:

"Albert Ewing of Nashville, Tennessee, delegate of his state to the governing body of the American Bar Association, for part of the South; Chester T. Lane of New York City, former general counsel of the Securities and Exchange Commission, for New York and New Jersey; Clarence A. Miller, of Washington, D.C., vice-president and general counsel of the American Short Line Railroad Association, for the District of Columbia, Maryland, Virginia, and West Virginia; Morris Mitchell, practicing attorney of Min- neapolis, for Wisconsin, Minnesota, North Dakota, and South Dakota; Charles 13. Stephens of Springfield, Illinois, executive secretary of the Illinois State Bar Association, for Illinois and Indiana; Robert G. Storey of Dallas, Texas, Dean of the Law School of Southern Methodist University and president of the Texas State Bar Association, for Louisiana, Oklahoma, and Texas; and Glenn R. Winters of Ann Arbor, Michigan, secretary-treasurer of the American Judicature Society, for Michigan. In addition, Chicf Justice Carl V. Weygandt of the Supreme Court of Ohio and Associate Justice John V. Spaulding of the Supreme Judicial Court of Massachusetts agreed to cooperate in the same work on an entirely informal basis with respect to applicants from their respective states. The original group of six consultants have aided in the regional work at their places of residence."

35. First Report of the Consultants 16.

36. 65 Civil Service Commission Ans. Rep. 32 (1948).

37. The NLRB trial examiners allege that Judge J. Warren Madden of the Court of Claims, a former NLRB chairman, and Mr. Frank Bloom, a former Chief Trial Examiner of the NLRB, who were given as references by many of the incumbents, were not consulted by the Civil Service Commission investigators. The writer has also been told that the investigators reached all witnesses who would be productive, and, undoubtedly, 
Statements concerning the qualifications of the incumbent examiners were not obtained under oath and were made in confidence. ${ }^{33}$ These qualifications investigations were sent to the Board of Examiners, which then organized itself into panels of usually three members to give oral interviews and make ratings. ${ }^{39}$

The qualifying and rating decisions of the Board were completed in meetings during November and December, 1948, and sent to the Civil Service Commission. Every action of the consultant group vas, of course, theoretically subject to review and revision by the Commission. It was understood all along, however, that such would not be the case to the extent that matters of judgment in individual cases was involved. ${ }^{40}$ And, in fact, the Commission did not review the Board of Examiners' decisions but merely translated them into its official action. ${ }^{41}$

at least the incumbents' present superiors were consulted. In the NLRB the incumbents' superiors would be NLRB members and the Chief Trial Examiner and not the General Counsel and his prosecuting staff who are now separated from the judicial side of the NLRB. See Labor-Management Relations Act of 1947, 61 StAT. 139 (1947), 29 U.S.C. \$153(d) (Supp. 1948). However, the present General Counsel, who was formerly a trial examiner, and others on his staff also were most likely consulted.

38. The Civil Service Commission refuses as a consistent policy to release these statements or the names of the informants. "Because of its [Civil Service Commission's] lack of the subpoena power, the Commission must, in developing information, rely to a great extent on statements made as confidential disclosures. In such cases the Commission does not disclose either the evidence or the identity of the source of information. Anonymous statements are not considered as evidence and are given no weight in the decision." Federal Personner manual, c. A5, p. 4.

39. Mr. Matthews, who participated in all but one of the oral interviews, and Mrr. MIcFarland were most frequently members of these panels. This information was supplied by a staff member of the Civil Service Commission. Board members stated that they disqualified themselves in cases in which they felt they might be prejudiced or partial. First Report of the Consultants 14.

According to affidavits later filed with the Commission, the interviews were in the nature of cross-examination, and the integrity of the "old NLRB"-i.c., pre-Taft-Hartley" Board-seemed as much on trial as the capacities of the individual examiners. The disqualified NLRB trial examiners have objected to Mr. Henderson's participation in the panels interviewing them. Since Mr. Henderson or his firm had several complaint cases before the NLRB, it has been asserted that he was in the position of a counsel for disappointed litigants and hence was prejudiced against NLRB personnel. Arr. Henderson did not disqualify himself in voting on at least some of the NLRB incumbents whom he questioned at the oral interview.

40. First Report of the Consultants 23.

41. In the case of those persons who were to be placed on competitive registers (i.c. non-status incumbents and new applicants) the Commission's staff converted the Board's letter ratings into numerical scores and added the preference points to which veterans were entitled. Each non-status incumbent who was rated eligible was to have an opportunity to be appointed, if the lowest numerical rating reached in the regular order of certification did not exceed his numerical rating by more than five points. This was in accord with the operation of the Civil Service Commission's Regulation 3.107(a)(2), Federal Personnel Mianual, c. Z1, Part 3 (FPMI, Z1-221). 


\section{The Results of the Examinations}

On March 11, 1949, the results were announced. Status incumbents were first found either ineligible or eligible. If held ineligible, they were told why in one or both of two phrases: (1) "Overall Characteristics" or (2) "Lack of Sufficient Specialized Experience." Those found eligible could immediately be given absolute appointments by their agencies. Non-status incumbents and applicants ${ }^{42}$ found eligible were given ratings ranging from 70 to 100 (or higher because of the addition of veterans' preference points) and then ranked in order on registers for five different pay grades. ${ }^{43}$

Of the 212 incumbents rated, ${ }^{44} 54$, or 25.5 per cent, were found disqualified. The following table shows the results:

Status Incumbents

Non-Status Incumbents

Total
TABLE I

$\begin{array}{ccc}\begin{array}{c}\text { Total } \\ \text { Incumbents }\end{array} & \begin{array}{c}\text { Number } \\ \text { Disqualified }\end{array} & \begin{array}{c}\text { Percentage } \\ \text { Disqualified }\end{array} \\ 148 & 42 & 28.4 \% \\ 64 & 12 & 18.7 \% \\ \frac{212}{212} & \overline{54} & 25.5 \%\end{array}$

Table II, below, lists the agencies which had the largest percentages of absolutely disqualified incumbents.

In addition to the absolutely disqualified incumbents some incumbents were rated eligible only for lower grades than those they were holding-in effect accomplishing a demotion. Others holding war service or temporary appointments were rated eligible, but with numerical grades such as 71 or 72 , which would put them at the bottom of the register of eligibles where they could not be reached on certification under the procedure of taking from the top of the register. Still others were rated eligible but at grades which were below the classification range of the agency in which they worked. For example, while the

42. Only the cases of non-incumbent applicants received prior to November, 1948, had been rated by the Board of Examiners.

43. Fifty-two non-status incumbents and 212 non-incumbent applicants were placed in rank order on the five registers of eligibles. From the statistics released by the Board of Examiners, 61.5 per cent of the eligibles who were non-status incumbents and $78 \mathrm{per}$ cent of the eligibles who were non-incumbent applicants received scores of better than 80. No statistics have been released which would show the relative standings of the in cumbents and of the non-incumbents on the registers, because the Civil Service Commission has generally pursued its policy of releasing neither the names or the scorcs of the eligibles (except to each individual concerned).

44. Five additional trial examiners (recent appointments) were serving in the Faderal Government at the time but their cases had not been completed. See Finst REpont of the Consultants $18 \mathrm{n}$. 
TABLE II

Agency

U.S. Maritime

Commission

Department of

Agriculture

NLRB

Civil Aeronautics Board

Interstate Commerce Commission

Treasury
Number

Total In- - Dis-

cumbents qualified

\section{3}

5
41

30

48

17
Percentage

Dis-

qualified Stalus

Non-

Slalus

qualifying range in the NLRB is from $P-6$ to $P-S$, three examiners were rated eligible, but only at $\mathrm{P}-4$ or $\mathrm{P}-5$. This decision in effect blocked their continued employment by that agency.

In the National Labor Relations Board, used as a case-study, the results for the 27 incumbents whose services antedated the TaftHartley Act are shown in the following table:

\section{TABLE III}

Number found wholly unqualified at any grade ( $S$ status, 6 non-

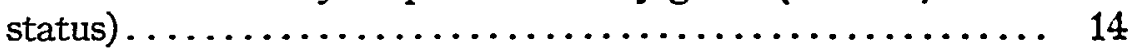

Number found qualified but at a grade below the NLRB's classification range. . . . . . . . . . . . . . . . . . . . . .

Number found qualified for placement on competitive register, but given scores so low as probably to preclude their appointment. .. 4

Number found qualified for grades within NLRB's classification range, but demoted one or two grades............. 5

Number found qualified at grade then held . . . . . . . . . . . 1

Thus 26 of the 27 with longest service were adversely affected. Over a period of years most of these 26 had received high efficiency ratings from the NLRB; in fact, of the 14 found wholly unqualified, 9 had received a rating of "Excellent," the highest rating possible. These melancholy results for the pre-Taft-Hartley Act hearing examiners were a striking contrast to the success of those examiners who had received temporary appointments after the passage of the TaftHartley Act on June 23, 1947. Of the twelve in this latter group, eleven were rated eligible by the Board of Examiners. 
On the same day the results were announced, the Commission gave the regulatory agencies until June 25, 1949 to displace all incumbent examiners who had been found ineligible or who had not received ratings high enough to come within certification from the registers. ${ }^{46}$ It also informed the agencies and the disqualified incumbents that they had 10 days within which to file an administrative appeal. Such an appeal, it was stated, should in each case set forth in full why the appellant was qualified and what factors were given inadequate consideration in the unfavorable decision.

\section{APPEALS}

The first step in an appeal from a civil service examination is in the nature of a rehearing before the Board of Examiners. ${ }^{40}$ If its decision is again unfavorable, there is a further appeal to the Commission's Board of Appeals and Review, which conducts a hearing de novo. ${ }^{47}$ And in the Commission's discretion there may be a subsequent appeal to the Commission itself. 48

Every affected agency noted an appeal on behalf of its examiners. In one form or another all asserted that a review of their examiners' records convinced them that the examiners were fully qualified to retain their jobs. The NLRB's letter said in part:
"The action has eviscerated the hearing examiner staff at a time when its case load is singularly great. 14 out of 28 members of the agency's old and experienced staff, including both status and war service incumbents have been rejected. The Board will be unable efficiently to pursue its regular operations without the services of these trained men, many of whom have been with the Board for over a decade." 49

Meanwhile the NLRB examiners who were ruled ineligible or other-

45. General Displacement Notice No. 27, March 11, 1949. The effective date of this displacement order was indefinitely extended on May 23, 1949, by Supplement No. 1. The plan of certification to be used was a so-called Plan B (Federal Personner ManUAL, c. R2, p. 26), under which each agency could submit requests for incumbent eligibles to be earmarked for certification. The names of these earmarked employec cligibles whose ratings came within reach of certification would thus be included in the certificates issued to that agency.

46. Federal Personnei Manuai, c. A5.

47. Ibid. Whether or not the Civil Service Commission's adjective regulations in the Federal Personnel Manual make the Board of Appeals and Review an independent tribunal in its appellate function is not clear. Cf. Federal Personnel Manual, c. A5-4 and the latest revision of $\S 01.8$ of the organizational regulations of the Commission, 12 FED. REG. 1271 (1947) ; 5 CODE FEd. REg. \$01.8 (Supp. 1947).

48. Federai Personnel Manual, c. A5.

49. The NLRB appeal is entitled "Notice of Agency Request for Reconsideration and Appeal," dated March 24, 1949. 
wise adversely affected banded together to secure common counsel for their individual appeals. ${ }^{50}$ These counsel wrote the Commission that it was a logical impossibility to meet the appellate requirement of stating which factors were given inadequate consideration in each case when they did not even know in what respects each examiner had been found wanting. Counsel joined the NLRB in asking for Bills of Particulars. Where "Overall Characteristics" was the offense, what did it really mean in each instance? Where "Lack of Sufficient Specialized Experience" was crucial, what experience was counted as specialized and what was not? In the interests of due process both the NLRB and the examiners' lawyers also insisted on an extension beyond the Commission's 10-day limit within which to present whatever evidence might turn out to be relevant. The appellants' past superiors, it was noted, were scattered from Germany to California. Finally they asked that incumbents be permitted to stay on the job until their appeals had been decided.

As a result of these letters the Civil Service Commission's staff prepared, on the basis of the investigator's record of each disqualified incumbent, a statement entitled: "Basis of Findings." 51 These statements were somewhat more specific than the individual notices of ratings. They did say what experience had not been credited as "specialized." And for "Overall Characteristics" they substituted terms such as "lack of fairness," "arbitrariness," "immaturity," "lack of judicial temperament and poise," and "biased in certain respects." The NLRB immediately wrote the Civil Service Commission that it did not consider these statements the adequate Bills of Particulars it had requested. The Commission at this time suspended its June 25 deadline and agreed that no incumbent should be dismissed until his appeal had been disposed of. ${ }^{52}$

On April 18, 1949, to find out how reconsideration by the Board ot Examiners would proceed, a meeting with Mr. McFarland, Chairman of the Board, and Civil Service Commission officers, was arranged for representatives of all affected agencies and counsel for the appellant examiners. Mr. McFarland stated that for the purposes of the re-

50. It was their feeling that their mutual interest in the principle involved as well as their individual concern in the actions of the Board of Examiners merited an arrangement for pooling counsel's fee and an agreement that the expenses of appeals, until all remedies had been exhausted, should be borne equally by all in the agreement regardless of whether they were given eligibility or a higher score or grade at an earlier stage in the proceedings. Attorneys Charles A. Horsky and John $R$. Thompson (now on the faculty of the Yale Law School) of the law firm of Covington, Burling, Rublee, O'Brian \& Shorb reviewed the facts and then agreed to act as counsel for a nominal fee.

51. Thus the statements were in the nature of short briefs prepared by persons who had not participated in the Board of Examiners' decisions.

52. The Directors of Personnel of the various agencies were so informed by letters from the Commission. 
consideration proceedings it was unnecessary to ask for hundreds of letters asserting the competence and freedom from bias of the incumbents who had been disqualified. Such letters, he said, would invite undue publicity and would probably not meet the issues which had in fact been determinative. It was then arranged to have a separate preliminary conference for each agency. At each Mr. McFarland would tell a representative from the agency and counsel for its appellants what was "really wrong" with each examiner and what additional information would be useful. The NLRB's conference was arranged for May 11, 1949.

At that conference the cases of the fourteen totally disqualified NLRB examiners were discussed. Mr. McFarland informed counsel that the Civil Service Commission had suggested a more lenient standard on reconsideration-and that nine of the fourteen disqualified NLRB incumbents would just be called in for reinterview and then rated eligible. Then he went into what was "wrong" with the other" five. This was mostly a matter of "over-all characteristics," such as bias in favor of labor and lack of judicial temperament, and lack of specialized experience. The experience problem grew out of the fact that the Board of Examiners had ruled out work in various jobs under the pre-Taft-Hartley NLRB--such as associate attorney in the Trial Examining Division (a kind of apprentice trial examiner); attorney in the Enforcement Section, which briefed and argued cases taken to court; attorney in the Review Section, which analyzed intermediate reports of trial examiners and recommended their adoption or rejection by the NLRB itself; and confidential legal assistant to an NLRB member. ${ }^{53}$

$\mathrm{Mr}$. McFarland instructed counsel that their only job was to have appellants ready for reinterviews starting on May 16. Although he did mention that the current opinions of NLRB members would be helpful to the Board of Examiners, he added that a commission investigator would attend to that. ${ }^{54}$ Counsel further asked for a stenographic report and the presence of counsel at the reinterviews. Both requests were denied.

53. The interpretation given to the specialized experience requirement will be treated at pages $464-8$ infra.

54. Of course the NLRB was already on record in its appeal. Meanwhile a Civil Service Commission investigator went to the NLRB, but the members were not able to see him, and the investigator did not question them until the results of the reconsideration were announced.

The reasons why the NLRB members were not questioned by the Civil Service Commission investigator (at this time one year after the original qualifications investigation) is a severely contested point on which the writer has heard extremely contradictory explanations. Although it is important because of the fact that allegedly the qualifications evaluation of the appellants differed in the two investigators' reports of a year apart, the writer has not been able to determine to his satisfaction the reason for the delay in obtaining the interviews with the NLRB members. 
Meanwhile, counsel for the disqualified examiners decided to attack the validity of the proceedings conducted by the Board of Examiners. Motions to the effect that the Board of Examiners was without authority in examining incumbents were filed with the Civil Service Commission. A separate supporting memorandum of counsel for the NLRB examiners also alleged in detail economic and religious bias on the part of the Board of Examiners. ${ }^{55}$ In addition, it was requested that the Commission make available the data used by the Board of Examiners in making its determinations and provide for a full, legal hearing on reconsideration with a stenographic transcript and the right to suppoena, confront and cross-examine rwitnesses. ${ }^{\mathrm{to}}$

The three members of the Civil Service Commission heard oral arguments on these motions on May 6, 1949. Answering the contentions then advanced, the Civil Service Commission in an informal note to counsel stated that the procedure was the usual one for new positions and that it was not convinced that any irregularities had occurred.

The note from the Civil Service Commission to the NLRB counsel reserved the matter of bias and prejudice but asked for affidavits thereon. On May 17, 1949, counsel submitted a memorandum and twenty affidavits expanding on the bias and prejudice charge. No answer to this memorandum was received until after the reconsideration proceedings were completed by the Board of Examiners. It was not until just prior to the subsequent appeal proceedings before the Board of Appeals and Review that President Harry Mitchell gave expression to the Commission view of this charge. In a letter to the counsel he said that the Board of Appeals and Review would be alert

55. This was subsequently broadened to include charges of nepotism and favoritism. It was also alleged that several members of the Board were disqualified by reason of contemporaneous activities in cases against the United States (or in which the United States was interested) in apparent violation of $\$ \$ 281$ and 283 of new Title 18 of the United States Code. It asserted that these proceedings against the incumbent examiners were in effect removal proceedings and not carried on according to the requirements of the Administrative Procedure Act. It asserted that there was no legal authority for the appointment of a Board of Examiners consisting of persons outside of offieial federal service and that the Board of Examiners had performed functions not legally delegated to it by the Civil Service Commission and had deviated from its basic instructions in the terms of the Announcement for Examination for the position of Hearing Examiner. Finally it was charged that the Board completely departed from traditionally fair standards for rating personnel.

56. The following counsel joined in these motions, filed April 27, 1949, to the Civil Service Commission: Charles Fahy for an incumbent trial examiner at the Department of Agriculture; Paul Porter for an incumbent trial evaminer at the Department of Agriculture; William E. Leahy and Ben Ivan Melnicoff for incumbent trial examiners at the Department of Agriculture, in the Alcohol Tax Unit and at the Federal Power Commission; Charles A. Horsky and John $\mathrm{R}$. Thompson for seventeen ineumbent trial examiners at the NLRB; and $R$. Granville Curry for twelve incumbent trial examiners at the Interstate Commerce Commission. 
to prevent bias and prejudice from affecting its decisions. He did not deny that bias, prejudice and incompetence existed in the Board of Examiners.

Seventeen hearing examiners from the NLRB had reconsideration interviews. ${ }^{57}$ The results of the reconsideration, which with one exception were approved without review by the Civil Service Commission, were announced about June 10,1949. Of the seventeen who were reinterviewed, eight (instead of the five Mr. McFarland had mentioned were still "in trouble") were found still completely disqualified. One was told that there had been a clerical error and he had really been qualified from the first. Three war service or temporary incumbents were found qualified at very low ratings or at grades below their present rank. One status incumbent was found qualified for a P-5 position, although the lowest grade held by a hearing examiner in the NLRB is a P-6.

Also, the Board of Examiners reversed itself with regard to the Chief Trial Examiner and two Associate Chief Trial Examiners. Previously the Board had decided that they were not doing "real examiner work" and therefore would not be considered incumbents. ${ }^{63}$ One was rated disqualified and two were rated eligible for registers with intermediate or low scores. This decision was made in spite of the fact that these men had competitive status and had heard half as many cases each year (usually the most difficult ones) as the average examiner, along with their administrative work of assignment of cases, supervision of the docket and record-keeping. Furthermore, the decision of the Examiners had been in plain contravention of Civil Service Commission Regulation 34.2 (f) which provided that the determination of whether or not a particular position was a hearing examiner position was to be made by the Commission's Classification Division. ${ }^{59}$ On reconsideration the Chief Trial Examiner and two Associate Chief Trial Examiners were treated as status incumbents and found eligible, but only for a lower grade than they were holding.

No decision was announced in one case, probably because there was then pending in the Supreme Court a case in which a court of appeals had vacated an NLRB order on the ground that the examiner

57. In addition to the fourteen disqualified incumbents, these included the Chicf Trial Examiner and one Associate Chief Trial Examiner, who possessed civil scrvice status but had been rated merely for the open competitive register, and the other Associate Chief Trial Examiner, who had been disqualified. The Chief Trial Examiner and the one Associate Chief Trial Examiner were told at their interviews that they would be treated as the other status incumbents, and the one Associate Chief who had been disqualified was told he would qualify and be treated as a status incumbent. Others had interviews which were similar to their first interview.

58. First Report of the Consultaints 13.

59. Frderat Personnel Manual, c. Z1, Part 34.1(F). These Regulations were issued as of September 23, 1947. 12 FED. REG. 6321-4. 
had shown bias against the company concerned. ${ }^{\text {co }}$ On June 20,1949, the Supreme Court unanimously reversed the court of appeals and went out of its way to praise the examiner's care and impartiality. ${ }^{\circ 1}$ A month later this examiner, a war service incumbent, was rated eligible but at a numerical score probably too low to permit his permanent appointment. ${ }^{62}$

The overall results of the recommendation appear in Table IV below. ${ }^{63}$ The table reveals that of the fifty-four incumbents absolutely disqualified on the original decision thirty-one were made eligible on reconsideration. This left twenty-three still disqualified of which eight were in the NLRB. ${ }^{64}$ In addition a number of non-status incumbents rated eligible on reconsideration received scores which were so low that their names would never be reached on the registers.

Soon after the results of the reconsideration had been announced, counsel for the eight NLRB hearing examiners who were still disqualified were informed that the de novo appellate proceeding would be held on successive days starting on June 20,1949, which was only seven working days later. In this limited time counsel were expected to prepare seven full appeals ${ }^{65}$ notwithstanding the fact that they had been told not to collect evidence until after the reconsideration had been completed. Counsel, of course, immediately protested. They contrasted this short time with the year which it took the Commission merely to provide for conditional reappointment of incumbents, with the fourteen months which it took the Board of Examiners to do their original job (January, 1948 to March, 1949), and with the three years which had elapsed since the Administrative Procedure Act had been

60. Pittsburgh Steamship Co. v. NLRB, 167 F.2d 126 (6th Cir. 1948). Since the examiner's first interview suggested that this decision was the main thing the Board of Examiners held against him, the examiner requested that the Board make no determination of his qualifications until the Supreme Court had disposed of the case. In contrast to its later action when the examiner had counsel, the Board ignored the request.

61. NLRB v. The Pittsburgh Steamship Co., 337 U.S. 656 (1949).

62. The examiner's counsel immediately sent a blistering protest direct to the three Civil Service Cormmissioners. They asked that his score be raised to 95 or that he be given a prompt and open hearing before the Board of Appeals and Review together with information of what objective factors, if any, were considered in the rating process and how the application of those factors resulted in such a low score. Shortly thereafter the Commission raised his score to 95 .

63. Upon occasion the Board has said that it made no recommendations of incligibility-that it merely passed on to the Commission without recommendation those whom it did not find qualified.

64. These figures are somewhat deceptive, because a few of the appellants were cleared on reconsideration by the fact that some time had elapsed since the Board of Examiners had tallied the incumbents' years of specialized experience and the incumbents had been building up time on the job.

65. One disqualified trial examiner was not represented by Attorncys Horsly and Thompson. 


\section{TABLE IV}

Board of Examiners' (Consultants') Results as to Incumbent Hearing Examiners

STATUS

Number qualified

Number found unqualified

Number not decided by Board prior to its resignation

\section{TOTALS}

NON-STATUS

Number qualified

Number found unqualified

Number not decided by Board prior to its resignation

\section{Totals}

\section{ALL INCUMBENTS}

Number qualified

Number found unqualified

Number not decided by Board prior to its resignation

Totals

\section{Original}

Decision

106

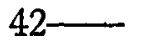

42

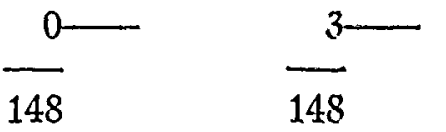

Decision

131

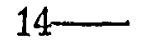

148
Reconsidered

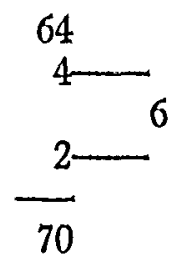

195

158

18 23
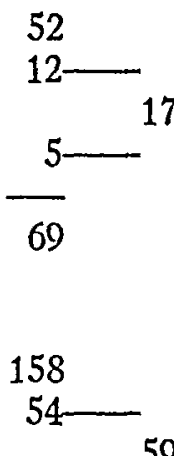

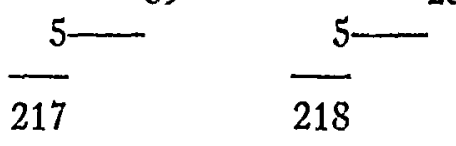

passed and the Commission had received whatever responsibilities it had in the selection process. Although counsel insisted that it was impossible to prepare an adequate appeal in the period allowed, the Commission adamantly refused any extension.

So that they might prepare cases and establish the procedure, counsel asked that appellants be furnished, before their hearings, with further particulars as to the reasons for their disqualification and the precise evidence which the Commission considered adverse to them; that a stenographic transcript be made at the hearings; that the Commission make available to appellants the subpoena power and inform them that it would pay witness fees as established in United States courts; ${ }^{66}$ and that the "Basis of Findings" of the Board of Examiners

66. Section 11 of the Administrative Procedure Act gives the Commission power to issue subpoenas and pay witness fees "for the purpose of this Section." 5 U.S.C. \$1010 (1946). 
be ignored in the proceeding before the Board of Appeals and Review because it was tainted with the bias and prejudice of the Board of Examiners. The Civil Service Commission denied all these requests. ${ }^{7}$

In the matter of a transcript, the Federal Personnel Manual states that a transcript is "usually" made of any hearing before the Board of Appeals and Review. ${ }^{68}$ In denying transcripts President Harry Mitchell stated that the Commission did not have adequate stenographic facilities available at that moment. When the appellants offered to bring their own stenographers the Commission still refused, without giving any reasons. ${ }^{69}$

Denied the subpoena power, counsel for appellants sent form letters to the appellants' past and present superiors and associates, and to NLRB, company, and union lawyers who had appeared before them. Most of the responses had not arrived by the date of the hearings, but an arrangement was made to send to the Board of Appeals and Review photostatic copies of letters as they were received. These letters were almost uniformly favorable.

The hearings before the Board of Appeals and Review occurred from June 20 to June $27,1949 .{ }^{70}$ All of the cases involved the examiners' "overall characteristics." Four of them also raised questions of whether experience in non-examiner positions in the NLRB should be counted as "specialized experience."

Counsel opened the week by presenting written and oral evidence by members and high officials of the NLRB to orient the Board of Appeals and Review on the organization of the Board, the functions of each component part, and the way in which each case ${ }^{71}$ progressed through the NLRB.

67. Counsel were informed by Chairman Edwards that the "Basis of Findings" (prepared as a Bill of Particulars to explain the reasons for disqualification) would be the fundamental framework upon which he would conduct his hearings. These rather indefinite Bills of Particulars would provide the only information as to the allegations which the appellants and their counsel would have to meet. However, further particulars would be read from the record, that is, the Civil Service Commission investigator's report, at the time of the hearing and not before.

68. Federai Personnel manual, c. A5-5.

69. Permission was given to counsel to dictate a "record" after the hearing, this record to be agreed upon by counsel and the Board of Appeals and Review. On the first day of the hearings the Board subsequently agreed to tell counsel, after the hearings, which decisions might be affirmed and to allow counsel to submit their version of the "reeord" and a brief on each. Counsel therefore spent each evening dictating that day's record. They were never told, however, that any single disqualification was likely to be affirmed.

70. The Board sat as a panel of three consisting of Chairman John F. Edwards, Alfred Klein, chief law officer of the Civil Service Commission, designated to sit on the Board for these cases, and other members of the Board who made up in turn the third member of the panel. The rotating members who sat in the NLRB appeals were Franl: J. Barley, Harold H. Leich, and David F. Williams.

71. In general the NLRB processes two types of cases: (1) "R" cases, involving 
Next each appellant was put on the stand. As soon as he was sworn the appellate board read aloud excerpts from the 1948 investigator's report which the Board of Examiners had used. Also read were excerpts from a new report-that which an investigator had apparently made in the week or two before the current hearings. "Someone said this about you" was approximately the phrase used to acquaint the appellant and counsel with some of the information, laudatory and derogatory, which was in the particular file. Here for the first time some of the accusations were made known. Counsel were then put to the task of questioning the examiner without any chance to consult with him or to investigate the just-revealed derogatory "evidence." In each case counsel also introduced written evidence showing that the appellants had received high efficiency ratings during their service with the NLRB; that neither the NLRB nor the courts had ever sustained a charge of bias against any of them; that each had a very high record of cases in which the parties had accepted his recommendations without challenge and of cases in which the NLRB and the courts had upheld his findings and conclusions against the challenge of a respondent.

After all the appellants had testified, counsel called to the stand a number of persons whose official duties had brought them into contact with some or all of the appellants and their work. Included among those who appeared were a former chairman of the NLRB, two exGeneral Counsels, a former Assistant General Counsel in charge of the Review Section, the NLRB's Solicitor and Assistant Solicitor, a high official in the Enforcement Section, the present Chief Trial Examiner and his two Associate Chiefs, and the Chief Legal Assistants to four of the NLRB members. Each was queried first about the specialized experience problem and then about the qualifications of the individual appellants. All testified to the high value to a hearing examiner of previous experience as an attorney in the Trial Examiner, Review, or Enforcement Sections of the NLRB and as legal assistant to an NLRB member. They were unanimous in the opinion that such experience should count as "specialized." They also testified with unanimity that the appellants whom they knew were both competent and impartial examiners.

As the week wore on several things became apparent. One was that the reports of the first, or 1948, investigation contained serious misstatements and omissions. In several instances cases were attributed to examiners who never had any connection with them. One appellant was described as the examiner most frequently reversed by the NLRB; in fact, the hearing showed, his percentage of affirmances was the highest of any examiner in the Labor Board's employ. Illustrative of another examiner's deficiencies, according to one report, which of two contending unions should be certified to represent a particular bargaining unit; and (2) " $C$ " cases, involving complaints of unfair labor practices. 
was a recent case in which a court of appeals had vacated an NLRB order based on his recommendations; the report failed to add that the NLRB was petitioning for certiorari and there was no follow-up to show that the Supreme Court subsequently reversed the court of appeals. Still another examiner was charged with pro-labor bias on the basis of two rulings which, the report said, were so clearly wrong that the NLRB summarily upset them; it developed that each ruling had really been upheld by both the NLRB and a court of appeals.

A second fact which emerged was the marked discrepancy between the reports of the first and the second investigations. Not only was the second report generally favorable to the examiners, but, according to the Board of Appeals and Review, some informants who in 1948 said that a particular examiner was biased in favor of labor did not repeat the charge in 1949. The Board expressed its disturbance at these facts and asked counsel to attempt a written explanation.

The requested memorandum opened by saying that it was impossible to do more than speculate about the discrepancies in the absence of any knowledge of who the informants were who had made particular statements. Several possible explanations were then suggested.

First, it was stated, the examiners had made very few rulings under the Taft-Hartley Act at the time of the first investigation. Their records had been made in the enforcement of the Wagner Act, which had been directed against industry. They had not yet had an opportunity to demonstrate their objectivity by applying the TaftHartley Act. By the time of the later investigation, however, they had been able to show that whether or not they agreed with the new Act they would apply it fairly. This, counsel suggested, was the reason some informants did not in 1949 repeat their charges of prolabor bias.

Secondly, the memorandum continued, labor relations had long been a bitterly controversial field and one in which loose charges of bias and prejudice have often been made. ${ }^{72}$ Moreover, there had been a sharp and acrimonious cleavage within the NLRB with regard to making changes of policy under the Wagner Act before Congress

72. Counsel illustrated this fact by an explanation along these lines: In this field a "pro-labor" accusation is often better evidence of where the accuser stands than where the accused government official stands. The Wagner Act itself was "pro-labor," and the appellants had admittedly tried to carry out the Act's policy in their decisions in the justifiable belief that any change in interpretative policy should come first from the Board itself and that any basic change in policy should be made by Congress by amending the statute. However, a difference of opinion on Wagner Act policy does not lead to the conclusion of bias and lack of objectivity. Yet that is what is often done in this field. One can believe that aduiterated food should not be permitted on the market and attempt to carry out the Food, Drug, and Cosmetic Act of 1938 without being "anti-business." The analogy is strained only because feelings seldom run as deep in a pure food hearing as in a labor hearing. 
amended it. ${ }^{73}$ The enmity that had thus been aroused, counsel alleged, was the probable cause of many of the derogatory statements in the first investigator's report. And they argued that the investigator never should have solicited views from persons known to be hostile to policies which it was the examiners' duty to enforce.

To date decisions have been issued in seven of the eight cases. All seven examiners were found qualified. Five of them had competitive status and hence are eligible for absolute appointment. The other two were given numerical ratings just over 80 . The eighth examiner had one of the strongest cases, and it seems almost certain that he too will be found qualified. If that happens it will mean that the Board of Examiners will have reversed itself or have been reversed in the case of all fourteen of the NLRB's incumbent examiners whom it originally wanted discharged.

\section{General Dissatisfaction with the Results}

Dissatisfaction with the actions of the Board of Examiners and the Civil Service Commission was registered in other quarters than the NLRB. Twelve incumbent hearing examiners of long service with the

73. The memorandum explained the way this cleavage developed. It was accentuated when Gerard D. Reilly became a member of the NLRB in 1941 and voted to change many of the Board's policies and to reinterpret the statute and thus became a dissenting member. Among those who agreed with his views on the NLRB staff was Mr. Robert Denham, then a trial examiner. This group constantly sought to change the direction of the NLRB. Some of those among it who were trial examiners attempted to do so by writing reports contrary to established Board policies. At one time Chairman Millis had to intervene and issue an instruction to trial examiners directing them to follow the policies set by the Board. This instruction, dated March 28, 1946, stated in part as follows: "The Board expects trial examiners not to deviate from Board policies as set in Board decisions, briefs, and public statements, in their Intermediate Reports. . . . The Board welcomes suggestions from trial examiners as to possible changes in Board policy, but such suggestions shall be made after the Intermediate Report has issued. The Board does not desire to discuss possible findings or recommendations with individual trial examiners before such issuance. . . . Trial examiners are, as heretofore, the sole judges of what findings of fact should be made in their Intermediate Reports." The NLRB majority felt that, if the trial examiners did not follow the Board policy, the work of the NLRB would be so greatly increased as to render implementation of the law extremely incomplete. Parties would litigate every case, even though all the NLRB precedents were against them, in the hope that they might get a trial examiner who would hold to the contrary. The Board itself would have to devote much time to writing opinions, reversing the trial examiners' reports and explaining that the latter were clearly contrary to the Board's precedents.

After Mr. Reilly left the Board, he became one of the principal architects of the Taft-Hartley Act which contained many of the policies he had unsuccessfully urged upon the Board. The Taft-Hartley Act provided for an independent General Counscl with broad policy-making powers. Mr. Denham was appointed to that position. A number of members of the old Reilly-Denham group were appointed to key positions under Mr. Denham. These are very likely the sources of some of the derogatory statements reported by the first investigator. 
Interstate Commerce Commission were found disqualified and ordered displaced. As a result the organized bar of the Interstate Commerce Commission, known as the ICC Practitioners Association, conducted a referendum of its membership. ${ }^{74}$ Of the total membership, 70 per cent voted on the question of whether to petition Congress for an investigation of the examination of the incumbent hearing examiners. Of these 98.1 per cent favored an investigation. ${ }^{75}$ Accordingly a letter of protest was sent to numerous congressmen, ${ }^{70}$ and in particular a memorial was given to Senator Olin D. Johnston of South Carolina, Chairman of the Senate Post Office and Civil Service Committee. Two quotations from the article in the ICC Practitioners Journal will suffice to reveal the strong stand which was taken:
"It seems almost inconceivable that the Administrative Pro- cedure Act which was intended, among other things, to insure se- curity of tenure of hearing examiners, and to prevent their re- moval only after a fair hearing should be so flagrantly violated in letter and spirit as appears to be true here." 78
"Not only does the action complained of do violence to one's sense of justice and fair play, but the Civil Service Commission's action is subversive of constitutional guarantees and democratic principles and ideals. The police state type of investigation has no place in American institutions. The professional standing (in the sunset of a life devoted to public service), social and professional reputation, and the very livelihood of each of these twelve men are destroyed ... without the opportunity to know their accusers or the accusations, much less to confront and cross-examine them." is

The ICC Practitioners at the same time aided the disqualified ICC hearing examiners in obtaining letters affirming their competence in their work for use in their appeals. ${ }^{80}$ On reconsideration ten were qualified for absolute appointment and only two remained disqualified, and since then the other two appealed and won their appeals. ${ }^{81}$

At the same time, the labor press began to carry articles about the disqualification of the NLRB trial examiners. These generally charged that the objective of the Board of Examiners was to replace incumbent

74. For an account of the actions of the ICC Practioners Association see Praclitioners Association Takes Strong Stand Against Civil Service Commission's Allampt to Discharge 12 Incumbent I.C.C. Hearing Examiners, 16 ICC Practitrosers J. 706-31 (1949).

75. Id. at 707 .

76. The replies are reprinted $i d$. at 711-16.

77. See Senator Wayne Morse's statement about this petition on the floor of the Senate, 95 Cong. REC 10835 (August 2, 1949).

78. 16 ICC PRACTTTIONERS J. 706 (1949).

79. Id. at 710 .

80. Id. at 707 .

81. Id. at $889 ; 17$ id. at 30 . 
hearing examiners with eligibles who had been highly rated because they were "safe" for business. Several of the newspaper columnists reported on the "house cleaning" performed by the Board of Examiners. Mrs. Eleanor Roosevelt in her column on May 28, 1949, was critical of the use of the non-governmental board:

"But to an outsider, such as I am, it is poor administration to take out of the hands of the people responsible, certain work which is important and which it would seem should be done by them. I can't understand why this work should be put into the hands of an extracurricular group, called in from outside the Government, which cannot possibly have the experience or the knowledge that long training in government would give them." 82

By this time members of Congress, assistants to the President, and the Assistant Solicitor General were asking for the facts. The private answer of individual Commissioners was that the inequitable results would be remedied quietly and piecemeal. It was also said or intimated that the Board of Examiners would be eased out of the picture: the Board had handled reconsideration of incumbents found completely disqualified, but the Commission's own staff would get to work right away reviewing the ratings of all who were eligible but competing with each other on registers.

The results were three-fold. First, the Commission made minor changes in the registers. Secondly, it put the registers into effect and told the agencies that new appointments must be confined to names certified from the registers. And, thirdly, the Board of Examiners resigned.

In Congress, dissatisfaction with the delegation of personnel-examining functions to individuals outside the Federal Service became vocal when, on August 2, 1949, Senator Wayne Morse introduced on the floor of the Senate an amendment to the Civil Service Commission's appropriation section of H. R. 4177, the Independent Offices Appropriation Bill for 1950. His amendment provided that the Civil Service Commission was not to use any of its appropriations for the compensation or expenses of a member of a board of examiners who had not filed an affidavit that he was not, or had not been within the fiscal years 1948 or 1949, interested in any proceeding before any federal agency or any other proceeding to which the United States was a party. ${ }^{83}$ In explaining the purpose of his amendment, Senator Morse briefly spoke of the authority given to the Civil Service Commission to determine eligibility for hearing examiners and the latter's delegation of this function to a group of outside consultants. He termed

82. My Day, May 28, 1949.

83. The amendment can be found in the House of Representatives print of the bill with the amendments of the Senate numbered, p. 14, lines 12 through 18. 
this delegation "a rather unfortunate incident" of questionable legality. ${ }^{84}$ The amendment was adopted by the Senate on August 2, 1949, but in the House of Representatives it was amended on motion of Representative Thomas of Texas to prevent a person with immediate interests in a particular agency from rating personnel in that agency. ${ }^{85}$ He may, however, rate personnel of other agencies in whose proceedings he has not appeared. Thus it was weaker than Senator Morse's original amendment which would have prevented the serving on boards of examiners of a person who had appeared before any agency in any proceeding. This House substitute amendment was quickly passed by the Senate, ${ }^{86}$ and was enacted into law as part of Public Lay 266 by the signature of the President on August 24, 1949.

Meanwhile other members of Congress had become interested in the results of the Board of Examiners' activities and the charges which had been made about them from various sources. Senator Johnston, Chairman of the Senate Committee on Post Office and Civil Service, became interested initially because of the representations made to him by the ICC Practitioners Association.87 Later, counsel for some of the NLRB applicants and incumbents as well as interested attorneys who had no clients in either category laid before him evidence of alleged nepotism and favoritism. Included were names of persons who had obtained very high scores and also were connected in various ways with members of the Board of Examiners. These specific accusations were also presented to the Civil Service Commission in support of the original motion alleging bias and prejudice on the part of certain members of the Board of Examiners. On July 28, 1949, Senator Johnston introduced in the Senate the following resolution, which was referred to the Committee on Post Office and Civil Service:

"Resolved, That the Committee on Post Office and Civil Service,

84. 95 Cong. Rec. 10835 (August 2, 1949).

85. 95 Cong. Rec. 11738 (August 15, 1949). The amendment reads as follows: "No part of the appropriations herein made to the Civil Service Commission shall be available ... for the compensation of expenses of any member of a board of examiners (1) who has not made affadavit that he has not appeared in any agency proceeding within the preceding 2 years, and will not thereafter while a board member appear in any agency proceeding, as a party, or in behalf of a party to the proceeding, before an agency in which an applicant is employed who has been rated or will be rated by such member; or (2) who, after making such affadavit, has rated an applicant who at the time of the rating is employed by an agency before which the board member has appeared as a party, or in behalf of a party, within the preceding 2 years; Provided, That the definition of 'agency;' 'agency proceeding' and 'party' in Section 2 of the Administrative Procedure Act shall apply to these terms as used herein."

86. 95 Cong. Rec. 11679 (August 15, 1949).

87. At this time, Miss Frances Perkins, one of the Civil Service Commissioners, went to see Senator Johnston about this matter and explained that regular Civil Service personnel examiners would review the work of the Board of Examiners. Such a separate review subsequently took place. 
or any duly authorized subcommittee thereof, is authorized and directed to make a full and complete study and investigation with respect of activities of the Civil Service Commission in determining qualifications for appointment of examiners under section 11 of the Administrative Procedure Act, including the activities of any advisory committee appointed by the Commission pursuant to such section. The committee shall report to the Senate at the earliest practicable date the results of its study and investigation together with such recommendations as it may deem desirable." 88

Subsequently, Senator Johnston drew from the Senate Post Office and Civil Service Committee a subcommittee to investigate the whole selection process for hearing examiners. No hearings were held prior to the adjournment of the First Session of the Eighty-first Congress. However, the status quo was maintained by a request from the Senate Post Office and Civil Service Committee that the Civil Service Commission cease certifying names from the five registers for absolute appointment until an investigation of the hearing examiner situation had been made.

On December 13, 1949, the Commission confessed error. It formally announced that the five registers "will no longer be used for absolute appointment." The Commission, the announcement continued, "has decided to review the qualifications of all applicants who filed in the open competitive examination and to conduct investigations in the cases of those who meet the experience requirements of the examination announcement." After this is done, the Commission said, "the entire examination will be re-rated by our examiners." 89

\section{An Evaluation of the Examination}

The program for determining qualified hearing examiners was launched over two years ago. Thus far the results have been unworthy of the effort. The almost total retrenchment from the original action of the Board of Examiners, culminating in the Civil Service Commission announcement setting aside the registers, emphasizes the fact that the Civil Service Commission approached and initially handled the problem in an indefensible way. Lest this experience be too quickly forgotten and no lessons learned from it, an underscoring of the obvious seems in order.

There are two aspects to such an examination. First, even assuming that the Act was properly interpreted both as regards coverage and overall rating procedure, there were not adequate safeguards to guarantee each applicant a fair determination of his case. The second aspect

88. Sen. Res. 143, 81st Cong., 1st Sess. (1949).

89. Civil Service Commission Departmental Circular No. 592, Supp. 3 (DC 592, S.3) (December 13, 1949). 
is broader. The objective of the Administrative Procedure Act was to draft a formula for securing competent men who would be independent and free from subservience to the agencies for which they performed their statutory functions as presiding officers and initial finders of fact. But "competence" is irrevocably hinged on a determination of qualifications, and "freedom" is assured only if there is a proper selection body and provision for careful surveillance.

\section{Absence of Safeguards in the Procedure Adopted}

The discretion granted by the Civil Service Commission to the Board of Examiners to determine "qualified and competent" hearing examiners was far too broad. Although the Examination Announcement specified ten different rating factors to serve as standards, eight of these dealt with legal and judicial ability and were so generally worded that they left much room for subjective application. ${ }^{.3}$ For example, the "ability to make independent decisions in important matters," the "ability to be objective and free from influence of any kind which might affect impartial judgment," and the "ability to handle difficult situations and to make and effectuate practical solutions to problems" scarcely provided definite standards or guides to ensure objective judgment. The overall experience requirement that "applicants must show conclusively" that they are persons of "judicial temperament and poise" also lends itself easily to a subjective evaluation.

This grant of discretionary authority was greatly increased by the complete lack of any specification of the weight each rating factor would carry in the total rating. The Board of Examiners chose to lump together all rating factors and to rate each applicant and incumbent by a single letter grade.91 Thus vague overall evaluations were substituted for separate evaluations on each rating factor and became the determinations of judgment which the Board of Examiners felt should not be reviewable. Furthermore, any kind of review was made difficult by the Board's policy of not making adverse findings of fact and not explaining the reasons for disqualification (except in cases where specialized experience was lacking).

Among the safeguards should have been a clear regulation concerning disqualification of any member of the Board of Examiners who had a prejudicial association with an applicant's agency. Instead, each

90. Another rating factor dealt with "diversity of experience in legal procecdings." This factor was somewhat in conflict with the concept of "specialized experience" and "progressively responsible experience" set forth in the Announcement, for diversity of experience is often not obtainable unless frequent job shifts have been made. Strict application of this factor would also tend to benefit private practitioners and to penalize government employees, because the latter generally are limited to the functions of a particular agency.

91. First Report of the Consultants 13. 
individual member was left free to make this decision. The mere grant of this discretionary authority in the controversial field of regulatory administration would undoubtedly have given rise to accusations that the Board of Examiners departed from traditionally fair standards of rating personnel. Unfortunately, several activities engaged in by the Board of Examiners added weight to these accusations. First, the Board members and the associates carried on recruitment activities contemporaneously with their examining functions. In addition, the decisions of the Board of Examiners were made in the vaguest of terms by the use of the two phrases: "Lack of Sufficient Specialized Experience" and "Overall Characteristics," and no further explanation for the disqualifications ever came from the Board..$^{92}$ Furthermore, the procedure for reconsidering the disqualified incumbents was not designed to disprove accusations that the Board was biased and prejudiced. No use was made of the subpoena power conferred by the Administrative Procedure Act in order to provide witnesses who could produce testimony openly and under oath which could be compared with information gathered in confidence. Nor were counsel for the disqualified incumbents allowed even to be present at the reconsideration interview.

As a result of the protestations made by counsel in oral arguments before the Civil Service Commission, the Commission promised to see that any bias and prejudice that might have tainted the actions of the Board of Examiners would be eliminated in the appeal before the Board of Appeals and Review. However, the procedure used by the Board of Appeals and Review hampered in a number of ways the adequate presentation of appeals and was not effectively designed to correct errors committed at earlier stages in the examinations. First, the time allowed appellants to prepare for the appeal was limited to one week. Second, the indefinite "Bases of Findings" were made the only allegations which appellants could prepare to meet. Third, there was no opportunity to obtain a record of testimony under oath in order to test the confidential records since the Commission would not supply a stenographic transcript of the appellate hearings. ${ }^{93}$ Fourth, the Com-

92. In Fink v. Finegan, 270 N.Y. 356, I N.E. $2 d 462$ (1936), the New York Court of Appeals condemned an even less vague reason for disqualification, namely, "lacking in force and executive ability."

93. Certainly, if the stenographic facilities were not available, this fact was another reason to delay the proceedings which had been scheduled on such short notice. Furthermore, as has been pointed out, the Commission was denying these incumbent hearing examiners the normal procedure accorded to appellants before the Board of Appeals and Review. Yet the various special protections in regard to removal of hearing examiners, unlike other civil servants, accorded by the Administrative Procedure Act (removal hearings for hearing examiners were made subject to all the procedural safeguards for adjudication as required by Section 5) attest to the fact that hearing examiners were to be treated as special cases in personnel actions. Therefore, if any personnel actions before 
mission denied the appellants the subpoena power and ignored their petition for payment of witnesses. ${ }^{94}$ Thus they were compelled to rely only on witnesses who were immediately available. In effect, the only precautionary action taken by the Commission to ensure an independent review untainted by possible errors by the Board of Examiners was the gathering by personnel investigators of a new file of confidential comments about the incumbents. Significantly these new records were much more favorable to the appellants than the first ones had been. ${ }^{96}$

When, in July, 1949, the Civil Service Commission began to review independently the ratings which had been made by the Board of Examiners and which, up to that time, had been left exactly as the Board determined them, the Board was naturally annoyed that the Commission's staff was undertaking this job on its own. It is thus understandable that the Board should have decided to resign. However, the Board's desire not to have its decisions subject to revision is not compatible with its other contention that as an advisory group of

the Board of Appeals and Review were to be granted a stenographic transcript-and the Commission's Personnel Mianual states that this is "usually" done-hearing examiners especially should be accorded such treatment. The implication is strong that the Commission was seeking to make it extremely difficult, if not impossible, for the appellants to get a full and fair review, by either the Commission itself or later by a court, of any adverse decisions which the Board of Appeals and Review might make.

94. The Commission's authority to use the subpoena power and to pay vitness fees is contained in $\S 11$ of the Administrative Procedure Act, 60 STAT. 244, 5 U.S.C. $\$ 1010$ (1946). Section 6(c) of the same Act provides: "Agency subpoenas authorized by law shall be issued to any party upon request and, as may be required by rules of procedure, upon a statement or showing of general relevance and reasonable scope of the evidence sought." 60 STAT. 240, 5 U.S.C. \$1005(c) (1946). Counsel for the appellants, faced with the difficult task of getting testimony concerning appellants from the many persons who had supervised or appeared before the appellants, had asked the Civil Senvice Commission whether it would extend the subpoena power if in each case they made a "showing of general relevance and reasonable scope of the evidence sought." The effect of the blanket denial was to say that no subpoenas would be issued regardless of what showing counsel made in individual requests. Up to this time they had been told that collecting hundreds of letters or statements by those who knew of the work of the incumbent cxiaminers was unnecessary. Now in seven days they were faced with this task

95. Washington columnist John Cramer, who strangely had private access to the investigators' records which the Commission refused to release to "anyone" (including the Senate subcommittee), has quoted from the confidential testimony of some of the NLRB members in the first investigation and pointed out discrepancies between this and their testimony in the second investigation. He concluded from this that the NLRB members were hoping that the Board of Examiners would disqualify a number of their hearing examiners, but later, when the results of the examination created widespread dissatisfaction, they changed their testimony in regard to the appellants. However, an equally plausible interpretation is that the first interrogation was unfairly conducted and reported. Only the absolutely disqualified incumbents had a second investigation. It is logical to assume that similar discrepancies would occur if new investigations were made on other incumbents who received low scores on the list of eligibles, but such an investigation has not been made. 
consultants it should not have to take the responsibility for any official actions in disqualifying and determining rank order. As an advisory board, it could be free of responsibility for the final decisions, but it could not then object to the fact that its advice was not taken in all instances. The Board of Examiners wanted to have it both ways, that is, to effectuate the outcome of its own actions and to have the Commission take the responsibility therefor in its stead.

Before the resignation, a situation had arisen in which the Board and the Commission were directly or indirectly casting the responsibility for the results of the examination on each other. The resignation of the Board of Examiners thus had the effect of placing the responsibility for the rectification of the results of the examination, if any were to be made, on the Commission, which in reality had to assume it anyway because the Board of Examiners received its delegated functions from the Commission in the first place.

\section{The Question of Specialized Experience}

Administrative agencies have grown up not only because courts could not handle the volume of adjudication and rule-making required under modern statutes granting wide discretion to administrative agencies but also to a greater extent because governmental regulation requires specialized personnel in the various fields of regulation involved. It is generally granted that specialized knowledge is valuable for the administrative and prosecuting staff in the regulatory agencies, but it is a matter of dispute whether such knowledge, previously acquired, is valuable for hearing examiners.

One school of thought looks upon hearing examiners as primarily judges, who, when presented with the evidence in an administrative case by the agency's counsel and the respondent's counsel, should know how to make a determination of facts based upon the weight of the evidence in the record, apply the law to the facts found, and frame an appropriate remedy calculated to effectuate the statute being administered or enforced. Hence, in this view, the qualifications for the position are judicial temperament and the ability to judge. Although the hearing examiner will become familiar with the subject matter and body of law in the field of regulation in which he participates, a specialized background in the field of regulation is not regarded as important. Some go so far as to advocate an examiners' pool from which an examiner may be selected for any case throughout the government. This idea, however, was rejected, when the Administrative Procedure Act was formulated..$^{96}$

The opposing view holds that it is very valuable for hearing ex*

96. "The section [Sec. 11] thus takes a different ground than ... other proposal for a completely separate 'examiners' pool' from which agencies might draw for hearing officers." SEN. Doc. No. 248, 79th Cong., 2d Sess. 215 (1946). 
aminers to be thoroughly familiar with a specialized field of regulation and its law in order that the administrative process can be expeditiously handled and the regulatory policy effectively carried out; that in fact an important purpose of the administrative process is to utilize skilled fact-finders as well as skilled fact-pleaders.

Prior public statements of at least two members of the Board of Examiners, Messrs. Willis Smith and Joseph W. Henderson, indicated that they were extremely hostile to the concept of administrative adjudication based upon a fund of specialized knowledge. The following passage of a speech by Mr. Henderson before the Nebraska Bar Association is typical:

"You are going to say that there are too many cases, and that our judges can't handle them. If that is their objection, then I say let's get some more judges. . . . All the courts need is a little more streamlining and they will be able to get things done just as fast and we'll have better justice when we're through. ... I I would still go back to the country doctor and lawyer and pit their knowledge and ability against all these specialists. We don't have to have specialists decide our cases. ... Therefore, let us not be hoodwinked by these people who want to change our form of government and get us away from our established form of justice into these administrative tribunals." 97

It would have been a fair guess that such vigorous views would color a board's estimate of what are and are not important qualifications. This indeed is what happened in the Board of Examiners' interpretation of the standards and experience requirements set forth in the Civil Service Commission's Announcement. The Announcement stated that any necessary "general experience" must have been obtained

"through legal practice or technical work performed in a field appropriate to the field in which hearings are conducted. ... This technical work must have provided a working knowledge of rates, fares, charges and practices of the industry concerned; accounting systems of the industry concerned; trade, labor or other practices of the industry concerned." 98

Also one of the rating factors to be considered was the applicant's "knowledge and experience in the technical subject-matter field involved in the position under consideration." 99 The Board of Examiners, however, decided that:

"For the lawyer, general experience is the private practice of his profession as general practitioner or in public service as a

97. 34 Proceedings-Nebrasea State Bar Assoclation 49, 53-54 (19:3) (reprinted in 22 NEB. L. REv. no. 4 (1943)).

98. EC-17 at 1 (see note 26 sipra).

99. Id. at 2. 
lawyer. For the non-lawyer, general experience must be closely related to what is hereinafter described as 'specialized experience' since otherwise the experience requirement would be meaningless." 100

Thus the Board of Examiners ruled out any technical knowledge in the general experience requirement for lawyers, despite the fact that the Announcement states otherwise. It went on to state that for the "general experience," the experience of a lawyer will not suffice if it consists only of "service as a lawyer in positions which may normally be filled by non-lawyers" or "administrative work or supervision, etc." 101 Thus lawyers who might have engaged in "technical work performed in a field appropriate to the field in which hearings are conducted" were not allowed credit for such technical experience in regulatory administration.

The specialized experience requirements of the Announcement were interpreted in an even more unauthorized fashion. The Announcement stated that the specialized experience had to be obtained in one of several categories of listed positions. They included positions as member, officer, or employee of a governmental regulatory body, who conducted formal hearings; made or recommended decisions on the basis of the record of such hearings; was responsible for the preparation or presentation of cases; or had administrative charge and responsibility for the successful completion of cases conducted before a court of record or governmental regulatory body. ${ }^{102}$ The Board of Examiners in its Rating Schedule for Hearing Examiners ${ }^{103}$ listed fifteen types of experience which were not counted as "specialized." Work as an "interviewer, field investigator, or sleuth" was not so considered, even though it might well amount to "the preparation . . . of cases" before a court or governmental regulatory body. "Administrative or supervisory work connected with public administration or regulation" was not so considered, even though it might well amount to "administrative charge and responsibility for the successful completion of cases conducted before a court of record or governmental regulatory body." "Work as a case or record reviewer of examiners' proposed reports or initial decisions" was not so considered, even though it might well amount to "recommended decisions on the basis of hearings."

The Announcement had also stated:

"In addition, the above experience [of one of the specialized categories] must have included, in the aggregate, participation in a sufficient number of important cases comparable to those coming

100. First Report of the Consultants 28-9.

101. Id. at 29. .

102. EC-17 at 2 .

103. First Report of the Consultants, Exhibit A, 28-31. 
before Federal regulatory bodies, to demonstrate a familiarity with problems which arise in the field of administrative law, and an ability to deal with these problems in a satisfactory manner." 104

This requirement was applicable to all types of experience cited as "specialized" in the Announcement. In spite of this, the Board of Examiners apparently did not apply this requirement to "experience as a judge, master, referee, hearing officer, or similar official of a court of record," for they mentioned these positions in their explanation of specialized experience with merely the qualifying phrase "doing the kind of work generally associated with typical judicial proceedings" but without the essential qualifying phrase of participating "in a sufficient number of cases comparable to those coming before Federal regulatory bodies." The implication is that judges and officials of a court of record were considered suitable persons to become hearing examiners without any experience with respect to cases in administrative law.

The Announcement had also included in italics at the end of the section on "Experience Requirements" the statement that

"Applicants' experience must have demonstrated, in connection with cases in one or more of the categories described above, a broad knowledge of the technical, legal, and economic factors likely to be encountered in such cases. . . ." 105

Notwithstanding this statement and the others which have been quoted above, the First Report of the Board of Examiners contained this statement:

"Of course the case of an incumbent or applicant will be aided to the extent that he can further show either diversity of experience or broad knowledge of the technical and other special factors involved in his field of special competence. It should be emphasized, however, that the consultants have sought generally apt, able, and temperamentally fitted examiners-not specialists in particular subjects such as radio, railroads, or rates." "1cs

It must be remembered, too, that the Board of Examiners made their alphabetical ratings on the basis of the rating factors considered as a whole without determining what ratings would obtain when applicants were considered in relation to "specific positions" to be filled. The effect of this procedure was thus to make the loose and subjective requirements of judicial temperament and poise, as viewed by the individual members of the Board of Examiners, to a very large extent the only rating factors involved.

104. EC-17 at 2.

105. Ibid.

106. First Report of the Consultants 9. 
The Civil Service Commission also helped to de-emphasize the specialized experience factor by its decision to have a register for each grade of hearing examiner which would apply to all agencies. Thus an applicant, qualified because of his specialized experience in cases involving the adjudication of claims for old age and survivors' insurance benefits, or the settlement of estates of Indians, could be certified to the NLRB for the position of hearing examiner in cases involving unfair labor practices. The Announcement provided for a procedure which might have avoided such a result. It stated: "As vacancies occur, the qualifications of the latter group [applicants who meet the basic requirements] will be evaluated in relation to specific positions to be filled." ${ }^{107}$ However, when the registers were actually made up, the Commission gave no indication that the eligibles rated in relation to these general standards of competence would be re-rated in relation to specific positions. Nor was there any indication that use would be made of selective certification, which would allow for the certification of those eligibles who have the specialized experience relevant to a particular agency's area of activity. ${ }^{108}$

One of the more amazing consequences of these departures from the Announcement was a determination by the Board that several incumbent hearing examiners were deficient in "specialized experience." A good argument can be made that "specialized experience" requirements are unnecessary for incumbents whose work is satisfactory to their agency since the purpose of having these requirements is to locate men whose training and background indicate they will probably be good hearing examiners in a particular field. An incumbent, however, can be evaluated on the work he has done in the position. This is particularly true in the case of a hearing examiner, whose rulings and decisions as a presiding officer are recorded in the transcript of the hearings and whose findings and conclusions are written and available in the form of intermediate reports. It should be enough if an analysis of these documents and the opinion of his superiors indicate that he has served satisfactorily. As counsel for the NLRB incumbents who were disqualified for the lack of sufficient specialized experience pointed out: "To disqualify a trial examiner because he fails to meet certain experience requirements is comparable to eliminating a successful college graduate because of supposed deficiencies in his high school training."

The deficiencies found by the Board of Examiners arose mostly because certain positions which the incumbents formerly filled were not counted as specialized experience by the Board of Examiners. In particular these positions were (1) attorney in the enforcement divi-

107. EC-17 at 2 .

108. Statements made to the author by a member of the examining staff of the Civil Service Commission. 
sion, (2) review attorney, (3) legal assistant to a board member, and (4) associate attorney in the trial examining division.

The enforcement attorney has responsibility for informing the Board as to the advisability of enforcement action in one of the United States Courts of Appeals and for preparing cases for presentation in these courts, and, if necessary, in the Supreme Court. In the original decision the Board of Examiners did not count such experience as specialized, but reversed itself on reconsideration. No reversal was made with reference to the other three types of positions. Accordingly the NLRB protested to the Civil Service Commission. The NLRB memorandum concluded with these words:

"Consistently with its position here taken, the Labor Board always deemed the work of the Review and Associate Attorney and the Legal Assistant as invaluable apprentice training for Hearing Examiner functions. Indeed, before the passage of the Administrative Procedure Act the Labor Board, as a general rule, required applicants who lacked such experience to serve a period of inservice training before being detailed to duty as a Trial Examiner. Time has confirmed the wisdom of this policy of thus utilizing the 'special competence' developed in the Labor Board's adjudicatory process to the very best advantage of the Government. Nor do we believe it necessary to mark the obvious merit of such experience in this 'special technical field,' when considered in contrast to that experience gained adjudicating 'claims for old age and survivors benefits, or the settlement of estates of Indians,' which, to the extent here involved, in sufficient amount qualified a Hearing Examiner for assignment to this Board by the standards enunciated in EC-17." 109

"In sum, it is our firm conviction that experience as a Review or Associate Attorney or Legal Assistant is the 'specialized experience' contemplated by EC-17. A contrary interpretation, we believe, would not only result in injustices to individual applicants, but would result in an unwarranted dissipation of special competence, to the Government's present and future detriment." 110

The rejection of the experience gained on the judicial side of the regulatory process is illustrated by the rating of applicants from the NLRB's judicial staff of legal assistants. Of the ten known applicants in this category, none was found qualified by the action of the Board of Examiners. Yet these are the men whom the Labor Board (essentially a labor court under the Taft-Hartley Act) had picked to aid them in making the final decision in cases involving unfair labor practices.

Opposition to the Board of Examiners' definitions of specialized

109. NLRB memorandum to the Civil Service Commission with a covering letter to the Board of Appeal and Review, 11-12 (July 12, 1949).

110. Id. at 12 . 
experience was not confined to the NLRB. The ICC Practitioners Association took similar exception to these views of the Board of Examiners. One of the ICC hearing examiners had been informed that his experience was clerical, since: "You have spent most of your time in the office of a Commissioner." 111 The ICC Practitioners Association replied that those familiar with the organization and functioning of the ICC know that "the Examiners assigned to assist a Commissioner in his office must be of outstanding ability and competence since they are relied upon heavily for advice and counsel in the performance of the Commissioner's duties." 112 The article continued:

"These twelve examiners are experts, possessing detailed knowledge of the problems which come before them. Their successors, should their discharge stand, are unknown and may well be untrained, inexperienced, and without understanding of the technical language and problems which they would be called upon to hear and decide. The idea, with which the consultants appear to be obsessed, that a commerce examiner is a mere umpire, or at the most has functions similar to that of a judge, is fantastic, to say the least. The judge deals with the finished product-the examiner participates in the making, and frequently in the design. No group of men, however eminent in its own field, is competent to pass upon the qualifications of such examiners until they, themselves, have become experts in the field. The logical body to select and direct ICC examiners is the Commerce Commission." ${ }^{113}$

\section{Use of Non-Governmental "Expert" Personnel Examiners}

The advisability of employing a board of expert examiners composed of members outside of the federal service depends on three issues: the legality of their appointment, their expertise for the job, and the propriety of choosing attorneys who had represented special interests before administrative agencies.

Undoubtedly the Civil Service Commission was under much pressure to constitute the Board of Examiners from among persons outside the federal service and more particularly from those who as critics of the administrative process had successfully engineered the passage of the Administrative Procedure Act. However, there were strong reasons why the Commission should not have consented to a membership composed of attorneys practicing before federal regulatory agencies. And the legality of their appointment is open to question. If sworn in as government employees, they would have been forced to give up their practice before federal agencies while so employed since the Federal Criminal Code prohibits governmental employees

111. 16 ICC PRACTITTONERS J. 706, 710 (1949).

112. Ibid.

113. Id. at $710-11$. 
from engaging in cases against the Government. ${ }^{114}$ When counsel for the appellants asked for information concerning the employment status of the Board of Examiners, the Commission refused this information. Later, in reply to a Senator's letter, the Commission explained that the members and the associates had not been sworn in as employees but were serving under contract pursuant to Section 15 of Public Law 600 of the Seventy-Ninth Congress. ${ }^{115}$ However, Executive Order $9830^{116}$ also governs the Civil Service Commission when it contracts for personnel examiners outside the federal service. Section 01.4(d) thereof reads: "Where qualified examiners are not readily available in the Federal Service, and to the extent permitted by law, the Commission or the agency concerned may designate and compensate individuals outside the Service especially qualified by experience and training to serve as examiners." 117 There is no record that the Civil Service Commission sought an opinion from the Attorney General as to the legality of contracting for the services of practitioners in cases before governmental agencies or that it made a finding that "qualified [personnel] examiners were not readily available in the Fed"eral Service." ${ }^{118}$ Whether the membership of the Board of Examiners was legally composed or not, the spirit of the law which prohibits having an interest against the Government while performing services for it and the spirit of the Executive Order which permitted the use of outside groups only where qualified examiners were not available in the federal service were disregarded.

The question of expertise is difficult to answer, because it again

114. Sections 281 and 283 are in the new Title 18 of the United States Code and were enacted into law in 1948 by the 80th Congress, but they were in the former Criminal Code in substantially the same form. These provide for criminal penalties for aiding in the prosecution of a claim against the United States or receiving compensation for any services in relation to a proceeding in which the United States is interested, while serving as an officer or employee of the Federal Government.

115. Act of August 2, 1946, 60 Stat. 810, 5 U.S.C. $\$ 55 a$ (1946). Section 15 provides: "The head of any department, when authorized in any appropriation or other act, may procure ... the intermittent services of experts or consultants ... by contract. ..." The Independent Offices Appropriation Acts of 1948 and 1949 so authorized the Civil Service Commission.

116. Exec. Order No. 9830 became effective on May 1, 1947. See Feneral Persoivirer MaNuAL, c. 21-203.

117. Id. at c. Z1-204.

118. Senator Miorse referred to the Commission's action in delegating the function of examination to a group of outside consultants in the following words delivered on the floor of the Senate: "shortly thereafter a question was raised as to the legality of this action, and it was suggested that the Commission obtain an opinion from the Attorney General sustaining the legality of its action. Had it done so, I think a rather unfortunate incident, about which I shall comment very shortly, could have been avoided. But, so far as I know, the Commission never saw fit to ask the Attorney General to give an opinion on its original action." 95 CoNG. REc. 10835 (August 2, 1949). 
depends on one's view about the specialized character of the administrative process. The ICC Practitioners Association, as noted above, contended that the Interstate Commerce Commission alone had the expertise to rate the qualifications of applicants for ICC hearing examiners. This view is in opposition to one interpretation of Section 11 of the Administrative Procedure Act, namely, that the Civil Service Commission is to determine those "qualified and competent" for these positions. The Commission acted on this latter construction but found itself lacking in personnel examiners who were specialists in administrative law. Although it had some lawyers on its staff, they could not function as personnel examiners of applicants for attorney positions in the federal service because Congress had consistently since 1943 inserted in the appropriation act for the Civil Service Commission:

"No part of the appropriations herein made to the Civil Service Commission shall be available for the salaries and expenses of the Legal Examining Unit in the Examining and Personnel Utilization Division of the Commission, established pursuant to Executive Order Numbered 9358 of July 1, 1943." 119

But even though the Civil Service Commission did not have experts in administrative law on its own staff, the different federal regulatory agencies had many such persons. These might very well have constituted a panel of personnel examiners for the position of hearing examiner. Indeed such a panel was constituted in the form of the original Advisory Committee which the Civil Service Commission set up pursuant to Section 11 of the Administrative Procedure Act. This Advisory Committee was, however, superseded by the Board of Examiners for Hearing Examiner Personnel which did not include in its membership a single expert in federal administrative law from the federal regulatory agencies.

Outside of the federal service, experts in administrative law are most likely to be found among persons who have studied intensively the federal regulatory process. They would include certainly members of the Attorney General's Committee on Administrative Procedure. However, only one of these members, Mr. McFarland, was placed on the Board of Examiners and he had joined in the so-called minority report of the Committee which the American Bar Association supported. However, none of the members who joined in the majority report without presenting additional views were made members of the Board of Examiners. Lloyd K. Garrison, Ralph F. Fuchs, Henry M. Hart, Jr., and Harry Shulman were members of this majority group of seven. If experts from outside the federal service are to be used at all, it would seem advisable to include at least one of the majority group. But all those mentioned are "school-men" whom the controlling leader-

119. Independent Offices Appropriations Acts 1944-50. E.g., 61 STAT. 585 (1947). 
ship of the American Bar Association did not think were as qualified as practitioners.

Practitioners are also a potential source of experts in administrative law. But if they are to be included on a board of personnel examiners for federal regulatory positions, they should not be drawn from those who serve business and industry alone. Excluding Mr. McFarland's representation of some of the Railway Brotherhoods in injunction proceedings, the principal clients of the three practitioners on the Board of Examiners came from this segment of economic life. In the membership of the Board, the government's regulatory agencies, the public, and competing political and economic interests were left without a voice.

But a wider representation of special interests would not really solve the problem and would indeed complicate it. Representatives or associates of any special interest group-be it business, labor, or agriculture-are bound to be suspected of partiality. Moreover, it is almost impossible to compose an adequate balance of immediately involved special interests on any panel. In effect, a board of experts composed of the various groups interested in regulation would become a battleground for conflicting interests rather than an effective device for the selection of hearing examiners. Furthermore, use of representatives of a special interest group to function as a board of expert examiners compromises the agency which uses them, generates counter pressures, and weakens that agency's ability to administer its duties objectively and impartially.

Since the Administrative Procedure Act entrusted to the Civil Service Commission the authority to determine the compensation of incumbent examiners and thus to make promotions (in order to free the hearing examiners from subservience to their agencies), any group to whom the Commission delegated these tasks would be responsible for periodically rating the work of each examiner by reviewing his findings and conclusions in his intermediate reports. If such a group then were composed of persons with a private and special interest, the way would be open for this private interest to penalize examiners by preventing the promotion of examiners who had rendered reports unfavorable to them. Interested parties would look over the shoulder of a hearing examiner as he wrote every report, as he made every resolution of the credibility of witnesses, and as he made every ruling about the admissibility of evidence and the conduct of the hearing. If these decisions turned out to be unfavorable to the special interest, the representative of that special interest on the rating board would be so informed. In effect, subservience to the agencies would thus have been replaced by a potential subservience to the litigants-a result hardly calculated to produce an independent corps of administrative judges and certainly outside the intent of Congress in enacting the law. 
The solution to this type of subservience is to exclude from rating boards for regulatory personnel any persons who are interested, pecuniarily or otherwise, in proceedings involving federal regulatory agencies. Senator Morse's amendment, which sought to create such a result, was eminently sensible, and the substitute amendment which was finally passed is helpful in excluding persons immediately interested in a particular agency. ${ }^{120}$

Because it is difficult to find such disinterested persons outside the Government (except, of course, for professors who are always open to the charge of being impractical theorists), the most feasible alternative is the use of experts in administrative law from other agencies of the Government. In this way hearing examiners will not be subservient either to the staff of the agency whose cases they hear, which subservience the Administrative Procedure Act intended to remove, or to outside private interests, which subservience the whole concept of the public interest in the administrative process opposes.

\section{The Civil Service Commission As a Guarantor of the Inde- PENDENCE OF HEARING EXAMINERS}

When Congress was considering what kind of agency should be entrusted with the authority of selection, compensation and removal of hearing examiners, it had three proposals before it. One was that of the Attorney General's Committee on Administrative Procedure which recommended the creation of an Office of Federal Administrative Procedure. The Office was to consist of (1) a Director appointed by the President by and with the advice and consent of the Senate, (2) a Justice of the United States Court of Appeals for the District of Columbia designated by that Court's Chief Justice, and (3) the Director of the Administrative Office of the United States Courts. ${ }^{121}$ This Office was to be given responsibility for the appointment of hearing examiners (the Committee used the term "commissioners") according to the following language of the Committee's proposed bill:
"He [the hearing examiner] shall be nominated by the agency, and shall be appointed by the Office of Federal Administrative Pro- cedure if that Office finds him to be qualified by training, experience and character to discharge the responsibilities of the position." 122

Under this proposed procedure the agency would select anybody it wished, but the appointment would follow only if the Office of Federal Administrative Procedure gave its approval. There would be no ranked register of qualified applicants as under the Civil Service Commission's

120. See note 83 supra.

121. Final Report of the Attomey General's Committee on Administrative Procedure, SEn. Doc. No. 8, 77th Cong., 1st Sess. 193 (1941).

122. Id. at 196. Section $302(3)$. 
procedure, and the agency would presumably have much more chance of adding to their staffs specialized hearing examiners.

Under this plan the hearing examiner would hold office for seven years and then would have to be renominated by the agency and reapproved by the Office of Federal Administrative Procedure. The minority report of the Attorney General's Committee accepted this scheme but extended the term to twelve years and provided that reappointments could be made by the Office without recommendation or intercession of the agency concerned. ${ }^{123}$ These amendments were designed to remove the threat of subservience to the agency on the part of the hearing examiner because of his desire for renomination at the conclusion of his seven-year term. Both the majority and the minority of the Committee agreed that removal should be made only for cause proved to the Office of Federal Administrative Procedure at a hearing in which either the agency itself or the Attorney General would prefer the charges.

The objections to the creation of an Office of Federal Administrative Procedure were that it would constitute another administrative agency, would be political, would interfere with the independent operation of regulatory boards and commissions, would constitute a super-administrative agency, and would serve unduly to emphasize and channel complaints respecting the administrative process. ${ }^{124}$

The second proposal provided for appointment by the Judicial Conference of a Director of an Office of Administrative Justice, who, with the advice and consent of the agencies concerned, would appoint (and fix the pay compensation of) competent hearing examiners. The Director would have the power to suspend or remove the examiners and would by rule regulate the conduct of examiners. The examiners would have the same security of tenure as is provided by the civil service laws. The objections to this scheme were that it would remove the examiners from real responsibility to the agency charged with the administration of law.

In preference to either of these proposals, Congress chose the third proposal of using the Civil Service Commission. The concepts that seemed to be predominant in congressional thinking were (1) that the agencies "have a proper part to play in the selection of examiners in order to secure personnel of the requisite qualifications," 125 and (2) that the guarantee of security of tenure by the Civil Service Commission was the appropriate way to ensure that the examiners would be

123. For additional views and recommendations of Mfessrs. MfcFarland, Stason and Vanderbilt, see id. at 221-3, 237-9.

124. SEN. Doc. No. 248, 79th Cong., 2d Sess. 42 (1946).

125. Statement in Congressman Francis E. Walter's extended remarls in the House of Representatives, Miay 24, 1946, reprinted id. at 371. 
free from subservience to their agencies. Representative Walter remarked:

"However, once selected, under this bill the examiners are made
independent in tenure and compensation by utilizing and strength-
ening the existing machinery of the Civil Service Commission. . .
If there be any criticism of the operation of the civil-service system,
it is that the tenure security of civil-service personnel is exagger-
ated. However, it is precisely that full and complete tenure security
which is widely sought for subordinate administrative hearing
and deciding officers. Section 11 thus makes use of past experience
and existing machinery for the purpose." ${ }^{226}$

As to the second congressional objective of tenure security, it is impossible to evaluate the two years of administration of Section 11 by the Civil Service Commission, because absolute appointments to hearing examiner positions as constituted by the Administrative Procedure Act have just begun to be made. As to the first congressional objective of giving the agencies a part to play in the selection of hearing examiners in order to secure personnel of requisite qualifications, the conclusion has been reached that the Civil Service Commission and its agent, the Board of Examiners, handled this assignment in a way which was very likely to undermine the specialized character of the administrative process and the forthright and honest execution of federal regulatory policies.

The effect of forcing the agencies to choose one of three non-specialized lawyers who have been given high ratings by the Board of Exam. iners, along with the displacement of experienced incumbents found disqualified by the Board of Examiners even though not found to have been biased or incompetent by their agencies or the courts, is necessarily to make federal regulation much slower and much less effective. This would be true not only because of the lack of experience of the new incumbents but also because of the fear of all incumbents of jeopardizing their promotion by impartially applying the regulatory statute they administer. An attempt to relax the effectiveness of federal regulation, although it can be legitimately sought by means of substantive changes in the statutory authority of the regulatory agencies, should not be camouflaged under the guise of an "improvement" in personnel. Whether the actions of the Civil Service Commission and the Board of Examiners were in fact such a subtle and adroit collateral attack on the effectiveness of federal regulatory activity or merely an honest attempt to secure competent personnel is not of consequence here. What is important is that these actions were likely to bring bad results.

Until last December the Commission publicly defended in toto all

126. Ibid. 
the actions of the Board of Examiners. Apparently it then hoped to placate its critics and avoid embarrassment by rectifying individual ratings. That was clearly not enough. The registers were necessarily affected throughout by the Board of Examiners' misconceptions about specialized experience, its disregard of the rating standards set forth in the Examining Circular, and its one-sided composition.

The Commission's eventual decision to discard these registers and proceed anew was a necessary first step. The next should be an immediate request to the Attorney General for an opinion on the limits of the Commission's authority in the selection process. Should that opinion coincide with the view heretofore taken by the Commission, several procedural changes would be vital. If registers are still to be used, separate ones should be established for each field of specialized regulatory subject matter; the subpoena power rather than assurances of non-disclosure should be relied upon to elicit information from reluctant witnesses in the course of the new investigations; the agencies should be allowed to appoint any applicant found to be "qualified and competent" instead of being arbitrarily restricted to the top segments of the registers. ${ }^{127}$ Also the Commission's announced intention of entrusting to its own staff examiners the task of rating the new examination seems inadvisable. The staff cooperated with the old Board of Examiners; and staff decisions are almost sure to elicit charges, justified or not, that the new examination is just windowdressing. Furthermore, it is at least questionable whether the staff examiners are as well qualified to establish the competence of hearing examiners as would be a board of professional experts in administrative law drawn from the regulatory agencies.

The Commission's December decision, however reluctantly made, restores its freedom of action. Opportunity to promote the public interest has replaced the temptation to contrive petty ways of muddling through and saving face. And the three Commissioners' unhappy experience in the preceding nine months should be ample notice that there are persons in and out of the government ready to devote time and effort to make sure that the hearing examiner program is truly conducted in the public interest.

127. This selection method may raise technical problems with regard to statutory preferences for veterans. These problems, however, should not have any bearing on the substance of the proposals here advocated. 


\section{THE YALE LAW JOURNAL}

\begin{tabular}{lll}
\hline VOLUME 59 & FEBRUARY, 1950 & NUMUER 3 \\
\hline
\end{tabular}

\section{EDITORIAL BOARD}

DONAID F. TURNER Editor-in-Chief

\section{Norman ReDLicH}

Executive Editor

\section{Arnold Horfman \\ Llewellyas P. Young \\ Comment Editors}

Monroe S. Singers Case Editor

Leo P. ARnaboldi, JR.

RICHARD M. FitzSrMINONS

Wititam E. Hegarty

JAXSES D. HHLBORN

\author{
EDWARD N. BENJAMIN \\ Article and \\ Book Review Editor
}

WilhiaM D. GinN

RICuARd F. IGL

Note Editors
ANDREW M. WOOD

Managing Editor

Gerald D. Katcher

DoNald L. MEDLock

ARTHUR M. MrCHaELSON

JEROME PRESTON, JR.

WHITNEX N. SEYMSOUR, JR.

\author{
MeLvin G. SurMa \\ ElLTOTT E. VOSE \\ RAYMSOND H. Youñ \\ EdGAR A. ZiNGMAN
}

$\begin{array}{lc}\text { MARIE MCMAgoN } & \text { RoBERT M. Canot } \\ \text { Business Secretary } & \text { Student Business Manager }\end{array}$

Subscription price $\$ 5.50$ per year

This ntmber, $\$ 1.00$

Canadian subscription price $\$ 6.00$ per year; Foreign, $\$ 6.25$ per year; for prices on other isstes inquire

The Yale Law Journal Company, Box $401 A$ Yale Station, New Haven, Conneclicut

\section{CONTRIBUTORS TO THIS ISSUE}

Boris I. BitTKer. B.A. 1938, Cornell University; LL.B. 1941, Yale University. Law Clerk to Judge Jerome N. Frank, 1941-2; Office of the General Counsel, Lend-Lease Administration, 1942-3; Chief, Liquidation Section, Office of the Alien Property Custodian, 1945-6. Associate Professor of Law, Yale Iaw School.

Arthur Nussbaum. J.D. 1898, University of Berlin. Professor of Law, University of Berlin Law School; Lecturer, Académie du Droit International de la Haye, 1933; member of commission for reform of German corporation law, 1926-S. Author of MONEY IN tee Law, Princtples of Private International Law, Conctse History of tue Law of Nations. Visiting Research Professor of Public Law, Columbia University.

Morgan Thomas. B.A. 1938, Lafayette College; M.A. 1940, Ph.D. 1946 Harvard University. Administrative positions with OPA, WPB, U.S. Army, and AMG, 1942-6. Instructor and Assistant Professor of Political Science, Swarthmore College, 1946-8. Assistant Professor of Political Science, University of Michigan. 